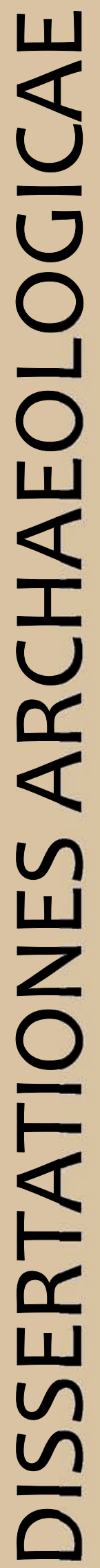

ex Instituto Archaeologico Universitatis de Rolando Eötvös nominatae

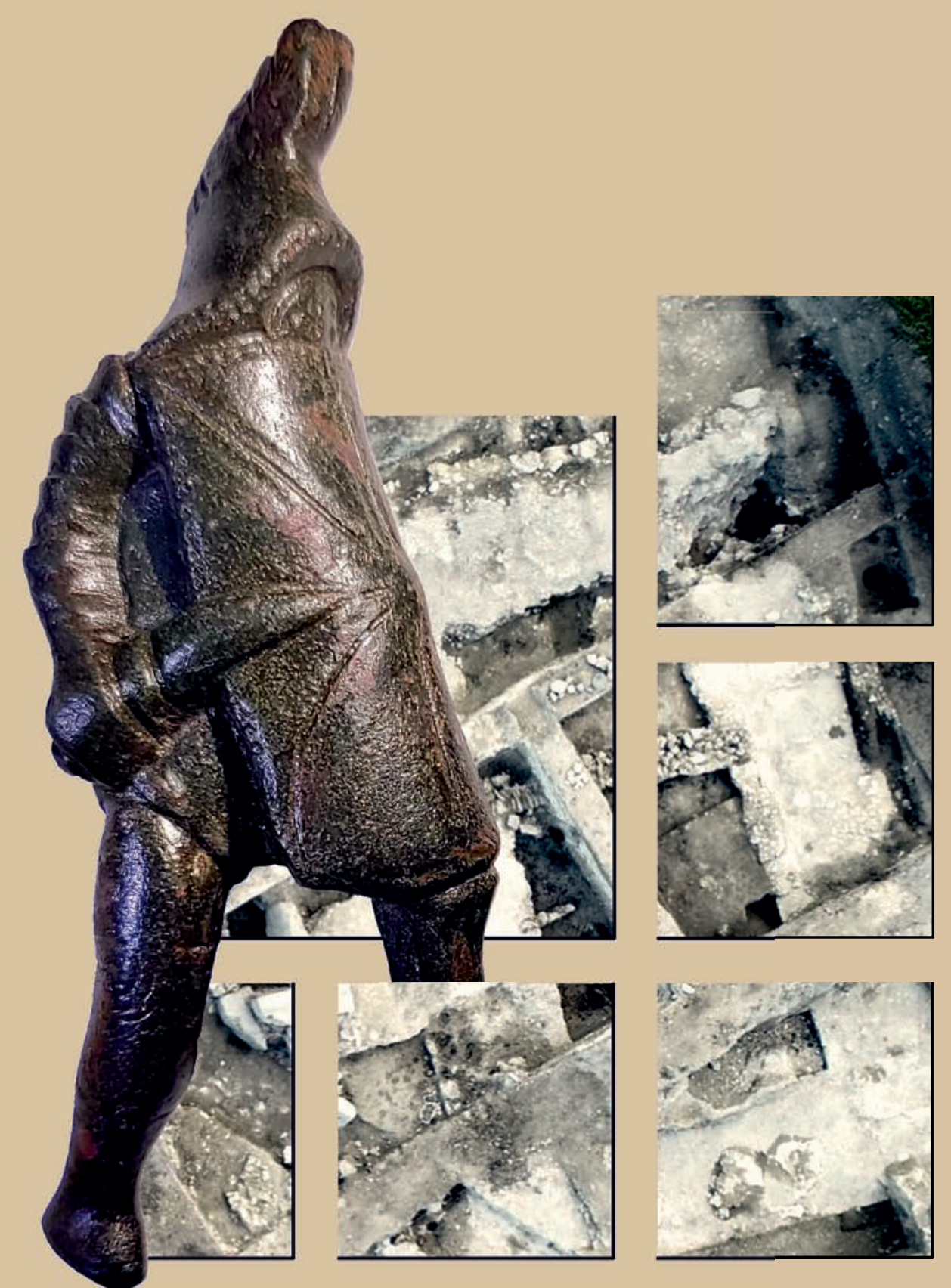

$$
\text { Ser. 3. No. 7. } 2019
$$




\section{Dissertationes Archaeologicae ex Instituto Archaeologico}

Universitatis de Rolando Eötvös nominatae Ser. 3. No. 7.

Budapest 2019 
Dissertationes Archaeologicae ex Instituto Archaeologico Universitatis de Rolando Eötvös nominatae

Ser. 3. No. 7.

Editor-in-chief:

DÁvid BARTUS

Editorial board:

LÁsZló BARTOSIEWICZ

LÁSZLÓ BORHY

ZOLTÁN CZAJLIK

IsTVÁN FELD

GÁBOR KALLA

PÁL RACZKY

MikLÓs SzABÓ

TivadAR VidA

Technical editor:

GÁBOR VÁCZI

Proofreading:

SZILVIA BARTUS-SZÖLLősI

ZsóFIA KondÉ

Aviable online at http://dissarch.elte.hu

Contact: dissarch@btk.elte.hu

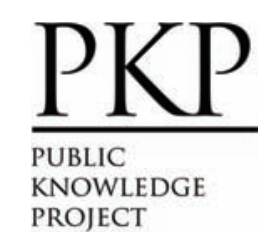

๑ ELTE Eötvös Loránd University, Institute of Archaeological Sciences

Layout and cover design: Gábor Váczi

Budapest 2019 


\section{CONTENTs}

\section{ARticles}

János Gábor TARBAY

The Casting Mould and the Wetland Find - New Data on the Late Bronze Age

Peschiera Daggers

Máté MeRvel

Late Bronze Age stamp-seals with negative impressions of seeds from Eastern Hungary

János Gábor TARBAY

Melted Swords and Broken Metal Vessels - A Late Bronze Age Assemblage

from Tatabánya-Bánhida and the Selection of Melted Bronzes

Ágnes ScHNEIDER

Multivariate Statistical Analysis of Archaeological Contexts: the case study

of the Early La Tène Cemetery of Szentlörinc, Hungary

Csilla SÁRÓ - Gábor LASSÁNYI

Bow-tie shaped fibulae from the cemetery of Budapest/Aquincum-Graphisoft Park

Dávid BARTus

Roman bronze gladiators - A new figurine of a murmillo from Brigetio

Kata DÉvAI

Re-Used Glass Fragments from Intercisa

Bence Simon

Rural Society, Agriculture and Settlement Territory in the Roman, Medieval and Modern Period Pilis Landscape

Rita RAKONCZAY

„Habaner“ Ofenkacheln auf der Burg Čabrad”

\section{FIELD REPORT}

Bence Simon - Anita Benes - Szilvia Joháczi - Ferenc BARnA

New excavation of the Roman Age settlement at Budapest dist. XVII, Péceli út (15127) site 


\section{Thesis Abstracts}

Kata SzILÁGYi

Die Silexproduktion im Kontext der Südosttransdanubischen Gruppe

der spätneolithischen Lengyel-Kultur

Norbert FARAGÓ

Complex, household-based analysis of the stone tools of Polgár-Csőszhalom

János Gábor TARBAY

Type Gyermely Hoards and Their Dating - A Supplemented Thesis Abstract

Zoltán Havas

The brick architecture of the governor's palace in Aquincum

Szabina Merva

'...circa Danubium...' from the Late Avar Age until the Early Árpádian Age-

$8^{\text {th }}-11^{\text {th }}$-Century Settlements in the Region of the Central Part of the Hungarian

Little Plain and the Danube Bend

Szabolcs Balázs NAGY

Noble Residences in the $15^{\text {th }}$ century Hungarian Kingdom - The Castles of Várpalota,

Ujlak and Kisnána in the Light of Architectural Prestige Representation

Ágnes KollátH

Tipology and Chronology of the early modern pottery in Buda 


\title{
Complex, household-based analysis of the stone tools of Polgár-Csőszhalom
}

\author{
NORBERT FARAGÓ \\ Institute of Archaeological Sciences \\ ELTE Eötvös Loránd University \\ faragonorber@caesar.elte.hu
}

\begin{abstract}
Abstract of PhD thesis submitted in 2019 to the Archaeology Doctoral Programme, Doctoral School of History, Eötvös Loránd University, Budapest under the supervision of Pál Raczky and Zsolt Mester.
\end{abstract}

\section{Introduction}

Papers on the Hungarian Neolithic rarely distinguished chipped stone tools systematically in a separate analysis before the last decades of the $20^{\text {th }}$ century. The formative phase of archaeology as a scientific discipline only focused on making collections, selections, and chronologies from every find and source types. The dissertation of Erzsébet Bácskay was the first of its kind, which draws a comprehensive picture of the Neolithic cultures of this territory through the evaluation of 303 tools from 35 sites. ${ }^{1}$ In this paper, she gathered together retouched examples from the Körös culture, Alföld Linear Pottery Culture, Szilmeg group, Transdanubian Linear Pottery Culture, Zselíz group, and Bükk culture.

The next synthesis was published in the 1980s, in which Małgorzata Kaczanowska investigated the Neolithic stone tool industries from the region of the Middle Danube. ${ }^{2}$ From this decade the different site reports became numerous also, Erzsébet Bácskay and Katalin T. Biró together published several chipped stone materials from Transdanubia, like the iconic site of Lengyel, Zengővárkony, Pécsvárad-Aranyhegy, Villánykövesd, and Mórágy-Tűzköves. ${ }^{3}$ Besides the aforementioned monograph of Małgorzata Kaczanowska, another fundamental work concerning the Neolithic period of the Carpathian Basin is the dissertation of Katalin T. Biró. ${ }^{4}$ Apart from gathering all the information about the raw material circulation during this period, she published 85 assemblages from the Middle Neolithic to the Early Copper Age in more detail, with an outlook on further 330 sites, sometimes from abroad.

During the 2000's the attention of the research turned partly to the Linear Pottery Culture and its genesis, and partly to the relationship of the Mesolithic and Early Neolithic population. Several site reports, monographs, and conference papers came to light in connection with these topics, while studies of Late Neolithic assemblages were extremely scarce.

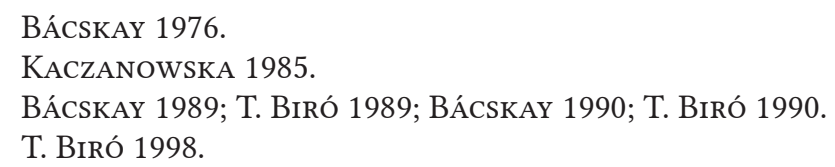


The Hungarian research reached a point during the last decade, where it became possible to follow finer technological differences through time, where it became possible to trace back different kind of raw materials, where natural science instruments or use-wear analyses became available, where local and regional contacts are well documented. In the meantime, there were hardly any analyses of the inner structure of a specific settlement, or there were barely any attempt to better understand the micro-scale social relationships through the chipped stone tools of this period.

\section{Site and material}

Polgár-Csőszhalom, located $3 \mathrm{~km}$ east of the modern town of Polgár in Northeast Hungary, has often featured in archaeological literature over the years, both in Hungary and abroad (Fig. 1). Vere Gordon Childe referred to this place as the eponymous site of the "Polgár culture", and he placed it chronologically among many other painted ceramic styles - Jordansmühl, Lengyel, Erősd, Vinča - in the "Danubian II" phase. The long history of research at this site began in the 1950s when Ida Bognár-Kutzián opened a small trench at the top of the mound. ${ }^{5}$

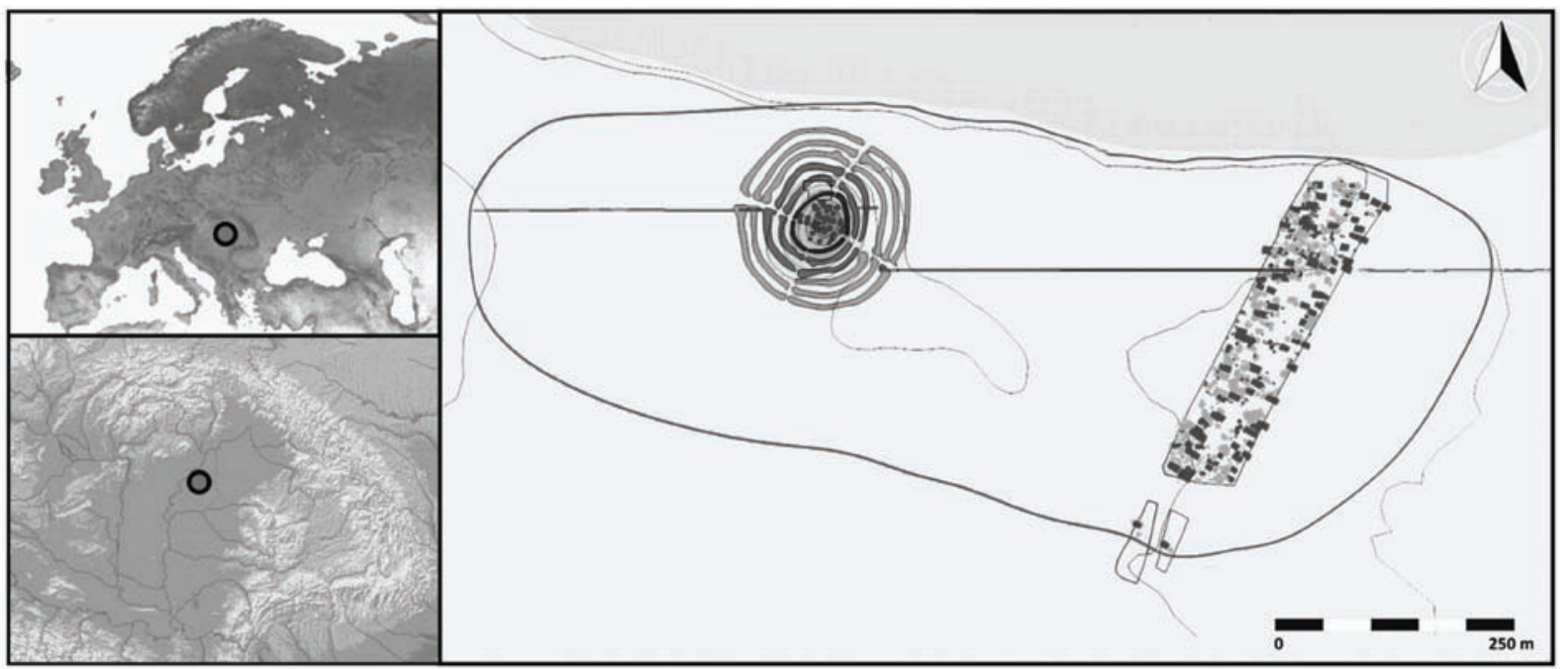

Fig. 1. Location and situation of Polgár-Csőszhalom.

In 1989, a new research project was initiated with the support of the Institute of Archaeological Sciences of Eötvös Loránd University (Budapest) under the direction of Pál Raczky. The project aimed to excavate as much as possible from the tell of Polgár-Csőszhalom. The preliminary magnetometric and aerial archaeological survey revealed a roundel of five ditches with a maximum diameter of 180-190 $\mathrm{m}$ and a palisade system surrounding the mound, which shed new light on the intensity of the relations with the Lengyel culture. ${ }^{6}$

Soon the fortuitous construction of the M3 motorway provided an opportunity to reveal that this tell was surrounded by an external settlement. From 1995 through several seasons, a 3.5 ha part of it has been systematically excavated, resulting in the discovery of more than 100 buildings, 123 burials, 68 wells, and more than 230 pits. Since then, more than a dozen preliminary and detailed reports have been published. The relationship between the two distinct settle- 
ment areas was investigated in more detail, on the basis of the assumption that the tell was not a simple residential mound; rather, it provided space for the ritual activities of the society. ${ }^{7}$ Concerning the chipped stone tools, only a few preliminary papers have discussed this site complex. Katalin T. Biró and Erzsébet Bácskay drew a general picture about the raw material composition based on a selected part of the collection only, while Erzsébet Bácskay published two short reports about the use-wear analysis of the retouched pieces. ${ }^{8}$

\begin{tabular}{|c|c|c|c|c|c|c|c|c|}
\hline & \multicolumn{2}{|c|}{$\begin{array}{l}\text { Horizontal settlement } \\
\text { part (Total) }\end{array}$} & \multicolumn{2}{|c|}{$\begin{array}{l}\text { Horizontal } \\
\text { settlement part } \\
\text { (Analysed from } \\
\text { closed context) }\end{array}$} & \multicolumn{2}{|c|}{$\begin{array}{l}\text { Tell settlement part } \\
\text { (Total) }\end{array}$} & \multicolumn{2}{|c|}{$\begin{array}{l}\text { Tell settlement part } \\
\text { (Analysed from } \\
\text { closed context) }\end{array}$} \\
\hline & $\begin{array}{l}\text { Number of } \\
\text { chipped } \\
\text { stones }\end{array}$ & $\begin{array}{l}\text { Weight of } \\
\text { chipped } \\
\text { stones }(\mathrm{g})\end{array}$ & $\begin{array}{c}\text { Number of } \\
\text { chipped } \\
\text { stones }\end{array}$ & $\begin{array}{l}\text { Weight of } \\
\text { chipped } \\
\text { stones }(g)\end{array}$ & $\begin{array}{l}\text { Number of } \\
\text { chipped } \\
\text { stones }\end{array}$ & $\begin{array}{l}\text { Weight of } \\
\text { chipped } \\
\text { stones }(\mathrm{g})\end{array}$ & $\begin{array}{c}\text { Number of } \\
\text { chipped } \\
\text { stones }\end{array}$ & $\begin{array}{l}\text { Weight of } \\
\text { chipped } \\
\text { stones }(\mathrm{g})\end{array}$ \\
\hline $\begin{array}{c}\text { Limnosilicite } \\
\text { type } 1\end{array}$ & 4369 & 68693 & 3432 & 55114 & 746 & 6967 & 664 & 6301 \\
\hline $\begin{array}{c}\text { Limnosilicite } \\
\text { type } 2\end{array}$ & 2592 & 54727 & 2335 & 43694 & 761 & 8781 & 670 & 7982 \\
\hline $\begin{array}{c}\text { Mezőzombor } \\
\text { type } \\
\text { limnosilicite }\end{array}$ & 1982 & 57888 & 1657 & 46500 & 2792 & 45725 & 2383 & 38427 \\
\hline Obsidian & 1351 & 6113 & 1119 & 5200 & 453 & 2451 & 382 & 2171 \\
\hline $\begin{array}{c}\text { Other } \\
\text { limnosilicite, } \\
\text { opalite }\end{array}$ & 1747 & 36681 & 1477 & 32680 & 696 & 9064 & 560 & 8064 \\
\hline $\begin{array}{c}\text { Felsitic } \\
\text { quartz } \\
\text { porphyry }\end{array}$ & 8 & 284 & 7 & 96 & 5 & 79 & 5 & 79 \\
\hline $\begin{array}{c}\text { Radiolarite } \\
\text { from Bakony } \\
\text { Mts. }\end{array}$ & 39 & 296 & 34 & 257 & 6 & 39 & 5 & 33 \\
\hline $\begin{array}{l}\text { Cracow } \\
\text { jurassic flint/ } \\
\text { chocolate } \\
\text { flint }\end{array}$ & 185 & 2063 & 137 & 1498 & 789 & 4026 & 628 & 3198 \\
\hline $\begin{array}{l}\text { Volhynian/ } \\
\text { Prut flint }\end{array}$ & 3 & 9 & 2 & 12 & 240 & 1249 & 182 & 958 \\
\hline \multirow[t]{2}{*}{ Other } & 76 & 1644 & 60 & 1086 & 124 & 1884 & 97 & 1364 \\
\hline & 12276 & 228401 & 10260 & 186137 & 6650 & 80091 & 5576 & 68577 \\
\hline
\end{tabular}

Fig. 2-3. Distribution of different raw materials at the flat settlement and the tell.

Including all excavation seasons and all parts of the surface assemblage, 18,926 chipped artifacts were collected from Polgár-Csőszhalom (Figs 2-4). All quantitative information in this paper, thus in the dissertation also reflects the last state of research. At some point the

7 RACZKY 1998; RACZKY et al. 2011.

8 BÁcskay - T. Biró 2002; ERdÉLyi-BÁCSKAY 2007; BÁCSKAY 2014. 
spreadsheets presented here contain different data from the already published preliminary information, which is the mere result of the evaluating method. All the assemblages went through a rigorous three-stage-revision, while the re-check of the documentation and the analysis of other categories of archaeological material were conducted parallelly. At some point the assemblage of the respective features had to be revised as new information or new pieces occured during the evaluation process. Among this quantity, 12,276 pieces belonged to the flat settlement part, while 6650 pieces came from the tell. Both places showed the same raw material spectrum, but not in the same ratio. $95 \%$ of the provenanced artifacts came from the Tokaj Mountains at the flat settlement part, moreover, $80 \%$ could have been attributed either to the three main types of limnosilicites or to the obsidians. The first and second types of limnosilicite are similar to that found in the Arka-Korlát region, so it is connected to the northwestern side of the Tokaj Mountains. The third type is already known within Hungarian literature as Mád-Mezőzombor type limnosilicite. ${ }^{9}$ Apart from these main subtypes, many other limnosilicites and opalites appeared at the settlement from many different types. Some stones are most likely connected to the same Arka-Korlát region, but others are likely from Erdőbénye, Gönc-Telkibánya, or Ohuta. ${ }^{10}$ Another part of the assemblage, namely obsidian also originated from the Tokaj Mountains; however, its genesis is a little bit different. Within the literature, there are two subtypes in the Tokaj Mountains: one is from

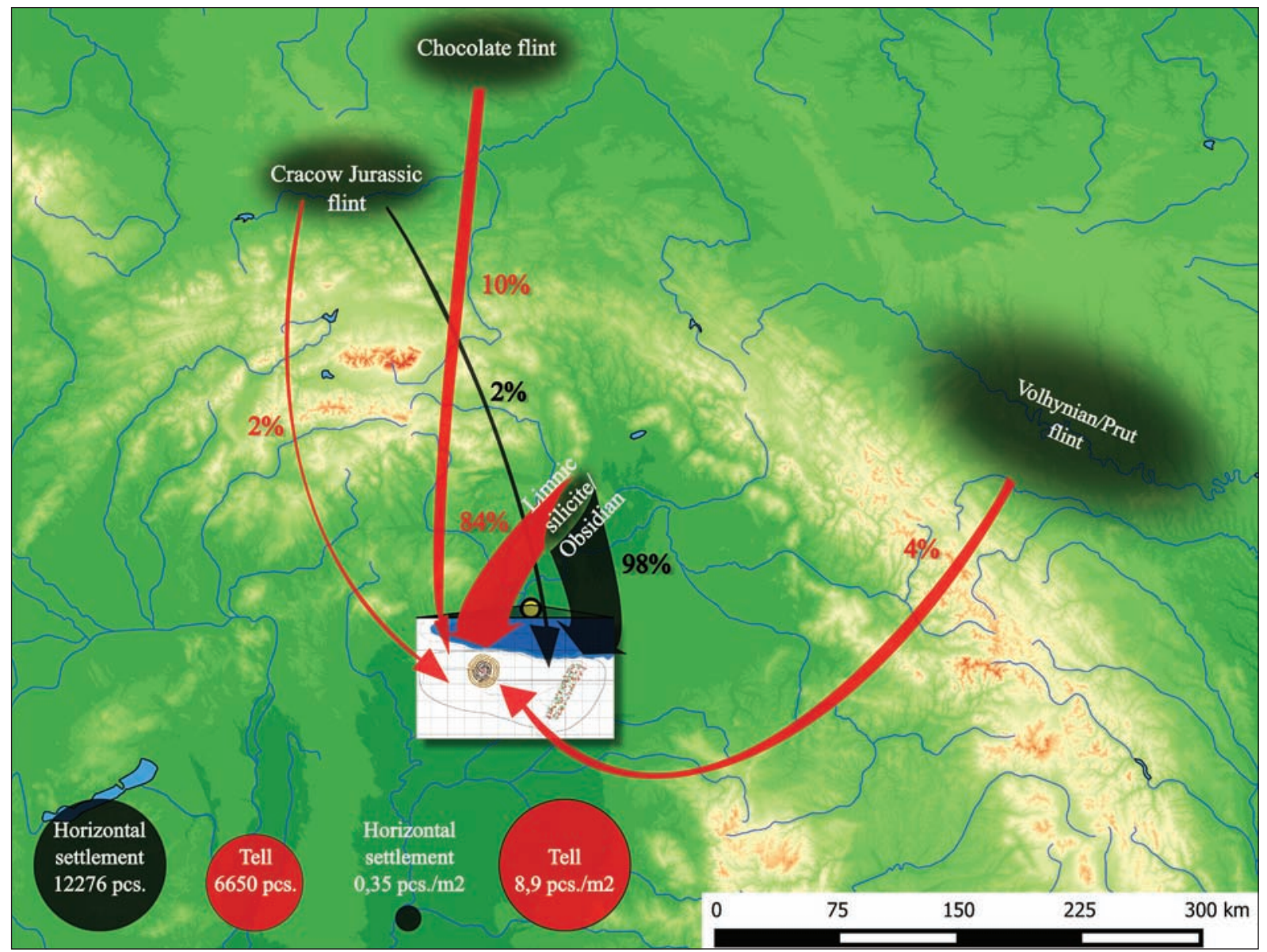

Fig. 4. Polgár-Csőszhalom and the ratio of different raw materials coming from different regions.

9 BÁCSKAY - T. Biró 2002, Fig. 11.

10 SZEKSZÁRDI et al. 2010. 
the Slovakian part and the other is from the Hungarian part. The former was more frequent in Polgár-Csőszhalom. Another raw material type can be found at a similar distance from the site but in a different direction. The quartz porphyry is from the eastern side of the Bükk Mountains, namely in the region of Bükkszentlászló-Bükkszentkereszt. The significance of this raw material lies in its general archaeological context, for it is more common within Paleolithic sites than Neolithic sites.

Also from Hungary, but at a 250-300 km distance from Polgár-Csőszhalom originates the Transdanubian radiolarite. It consists of several varieties in a wide geographical range from the Bakony Mountains to the Gerecse Mountains, but all of the pieces at this settlement belong to the Szentgál subtype. The Cracow Jurassic flint is from Little Poland, at a $250 \mathrm{~km}$ distance. The chocolate flint is very similar, and it comes from a Jurassic bedrock also, but its original outcrops lie farther north in the Holy Cross Mountains. The Volhynian/Prut flint came from the Volhynian-Podolian Plateau, from a typical Cretaceous bedrock at a $400 \mathrm{~km}$ distance from the site.

The raw material spectrum of the tell looked different, namely Cracow Jurassic flint, chocolate flint, and Volhynian/Prut flint are more frequent here, constituting $16 \%$ of the lithic assemblage. Another important difference is the abundance of the Mezőzombor type in this assemblage, as it reached 40 percent.

\section{Aims and methodology of the dissertation}

Our project started in 2012 in the framework of a complex household analysis. The first step to accomplishing such an analysis is to create a database by plotting all these finds independently of one another with their coordinates in a virtual map. ${ }^{11}$ This data set is arranged by archaeological sources - ceramics, stones, animal remains - forming distinct virtual layers. The second step is to reconstruct social groups on different levels with the aid of statistical and spatial analysis tools.

The chipped stone industry is very suitable for this kind of investigation, especially when a palaeoethnologic aspect is applied. The main idea behind this method is that every knapped piece can be replaced in the technological chain by reading the stigmas on it. ${ }^{12}$ When this mental reconstruction is connected with the locations of the respective chipped stone artifacts, much of the original toolmaking process can be visualized. Following André Leroi-Gourhan and his early research in Pincevent, the French Paleolithic research adapted this method during the 1960s, and since then it has been successfully applied beyond the borders of France also. ${ }^{13}$

Moving beyond these theoretical considerations it soon became clear that we have to deal with several complications to accomplish this research during the intra-site analysis of Polgár-Csőszhalom. Firstly, it was a rescue excavation in the frame of the construction of the M3 motorway, therefore the spatial information of the finds is confined directly to the spatial information of the archaeological features. It also means that our finds were picked up and

11 FARAgó 2015.

12 Texier - Meignen 2011; Tixier 2012.

13 Leroi-Gourhan - BrÉZillon 1983; GaudZinski-Windheuser et al. 2011. 
stored by stratigraphical units. Moreover, the settlement features were excavated with shovel and spade, not in a square-meter system with more precise methods, like dry/wet sieving. Unfortunately, this gives less precise results compared to those Palaeolithic examples where every find was recorded independently. In the meantime, the tell was excavated in a combined way, where both the former and later methods were applied. Concerning the site formation process, this is the most crucial part of the investigation as Michael Brian Schiffer pointed out. ${ }^{14}$ However, scholars of household archaeology often bypass or overleap this problem, especially in the case of large archaeological sites and assemblages. ${ }^{15}$

Secondly, there was no possibility of detecting the floor level of the houses at the flat settlement, because evidence of deliberate burning, which is common on the tell, is missing here. All the finds are just indirectly connected to the houses, if we are supposing that they were deposited into the closest settlement features (pits).

Thirdly, the Polgár-Csőszhalom settlement was inhabited over a long period, for 250-300 years according to the AMS dates, so it is necessary to pay special attention to the problems of horizontal stratigraphy. Furthermore, the theoretical question of the lifespan of the houses or the pits makes this aspect of the work more problematic.

The rough difference between the material of the horizontal settlement part and the tell part in itself is very important, considering their supposed roles in the lifetime of the settlement. But what does this differentiation really mean? Does it mean technological and typological difference also between the two settlement units? How can we imagine these processes in space and time in more detail? Does it mean that the distant raw materials were used only in a sacral context? What do the few distant pieces in the assemblage of the horizontal settlement really mean? Did some person or household express their identity or wealth with them? What if this difference is merely a result of some taphonomic effect of research strategy?

Being oriented by Richard R. Wilk and William L. Rathje, the pioneers of household archaeology, ${ }^{16}$ and by the theoretical paper about the household concept of Polgár-Csőszhalom, ${ }^{17}$ I would also like to emphasize the need of different aspects during the approximation of these basic units. Moreover, the various independent viewpoints mean various perspectives and various research strategies and methods, which idea was inspired on one side by the work of Geoff Bailey, ${ }^{18}$ on the other side by a paper about the various lifecycles and rhythms of activities at Polgár-Csőszhalom. ${ }^{19}$ Therefore my dissertation was themed around four different viewpoints: spatiality, temporality, symbology, and taphonomy. These aspects or problems have been constantly present since the start of the work, so it seemed best to organize the thesis rather around them, and not around the two different settlement parts or the raw material-technology-typology description.

14 SCHIFFER 1983; SCHIFFER 1996.

15 SMOLNiK 2012; Hamon et al. 2013.

16 Wilk - RAthje 1982.

17 ANDERS - RACZKY 2013.

18 BAILEY 2007.

19 RACZKY et al. 2015. 


\section{Spatiality}

When conducting an intra-site analysis it is very important to know as much as possible about the site formation processes..$^{20}$ In the case of Polgár-Csőszhalom, all of our finds came from secondary contexts from pit infills, so the possibility to reconstruct exact site formation processes thus activity zones is very restricted. In most cases, the archaeological structures lack any horizontal stratigraphy, so they could be dated with AMS, or ceramic finds. Another concluding problem that in most cases the well-known spatial analytical methods (e.g. nearest neighbor analysis) are not suitable for this research, because these are not applicable for lattice spatial processes, only for point spatial processes..$^{21}$ Moreover, these methods are not multivariate but univariate statistical tools. The method applied here can be defined as a hybrid one, because I used correspondence analysis without including the ' $\mathrm{X}$ ' and ' $\mathrm{Y}$ ' coordinate into the variable set. Statistics and graphical visualization were used parallelly but independently and intuitively, which means the evaluation cycle was continuous in a heuristic way. ${ }^{22}$ Kernel density analysis is a well-known analytical tool to illustrate archaeological find distributions, but instead Thiessen polygons were applied for this purpose, because I wanted to visualize the encircling impact zone of each feature. ${ }^{23}$
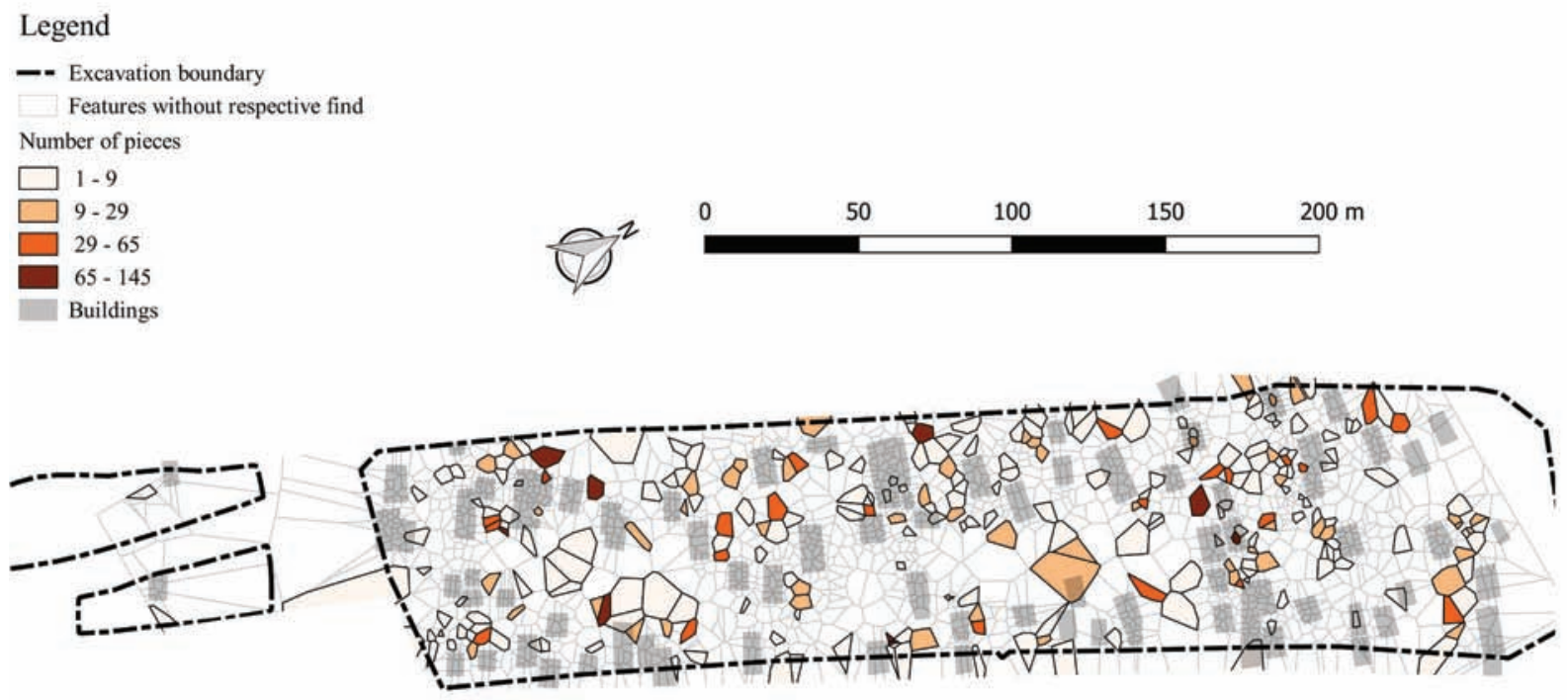

Fig. 5. Overall distribution of Type 1 limnosilicite (pcs).

If we take a look at the general attributes and consider the complete settlement as a whole, the distribution looks very homogenous, no matter which raw material, technological category or type it is about (Figs 5-8). ${ }^{24}$ It is very hard to prove the existence of activity zones that were used for only one, special purpose. According to the multiscalar investigations, the different aspects, and the statistical results these zones had multiple purposes during their utilization. Starting with the first step of the knapping activity, raw material nodules are not very frequent at the settlement. In general, all types of cores and debitage products appeared together, so it

20 SCHIFFER 1983; SCHIFFER 1996.

21 ORTON 1982.

22 Kintigh - Ammerman 1982.

23 Connolly - LAKe 2006, 173-177, 212.

24 FARAGÓ 2016. 
is not possible to encircle zones with corticated pieces in connection with the early phases of knapping, or to highlight the later knapping phases with the help of uncorticated pieces. Other byproducts like flakes, or half products like blades and blade fragments and finished tools, strengthen the same impression. Moreover, the different core exploitation strategies, which meant to reflect different knapping habits showed no concentrations on the settlement.

This homogeneity looks apparent only in a wider context, because smaller assemblages in close vicinity look rather different. These are not statistically relevant differences either, but features do exist in which one or another raw material, technological category or tool tends to accumulate in a moderate way. Although the pattern looks homogenous from a distance, by having a closer look the fine divergences may reflect spatially and/or temporally different

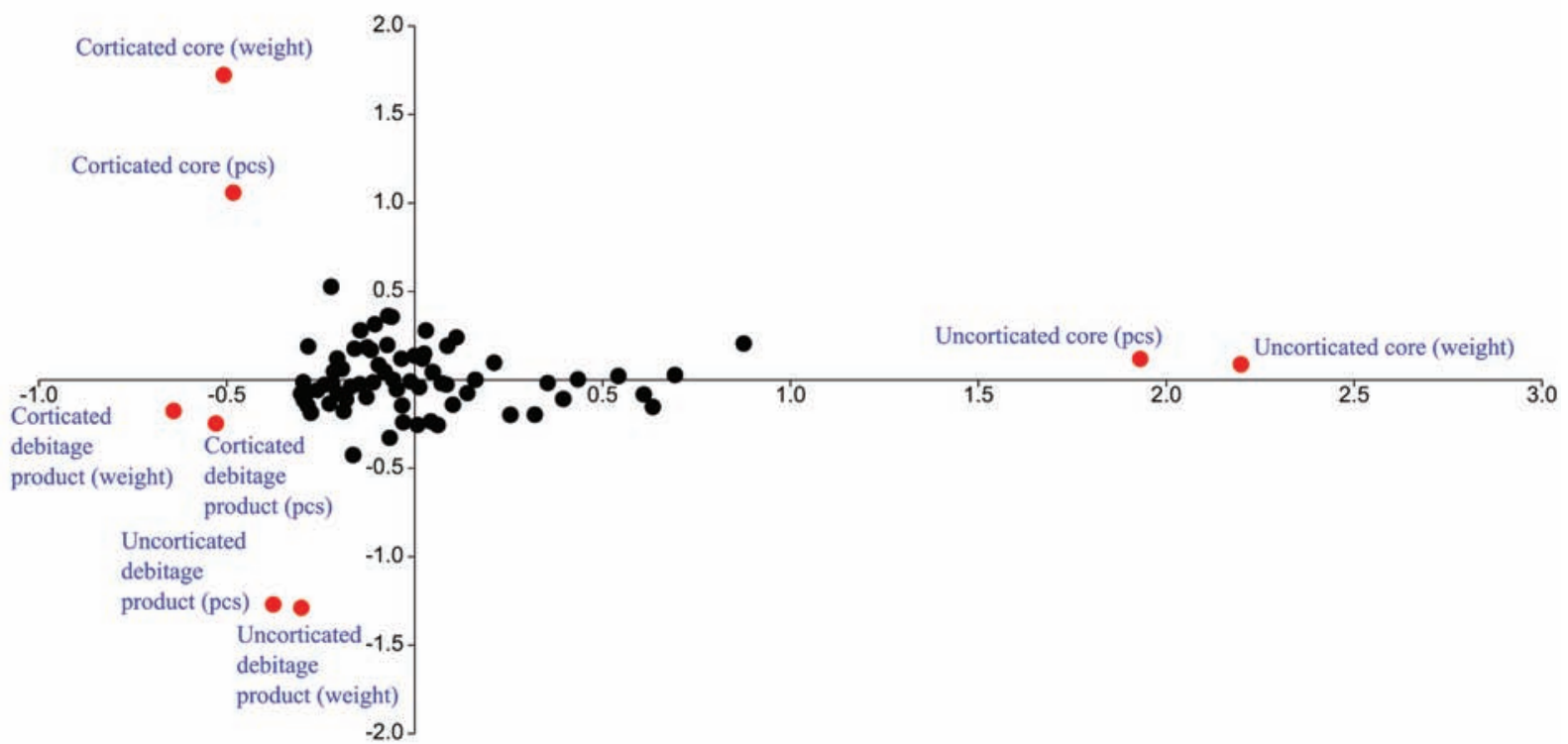

Fig. 6. Correspondence analysis of the rough technological categories of Type 1 limnosilicite and the different features.

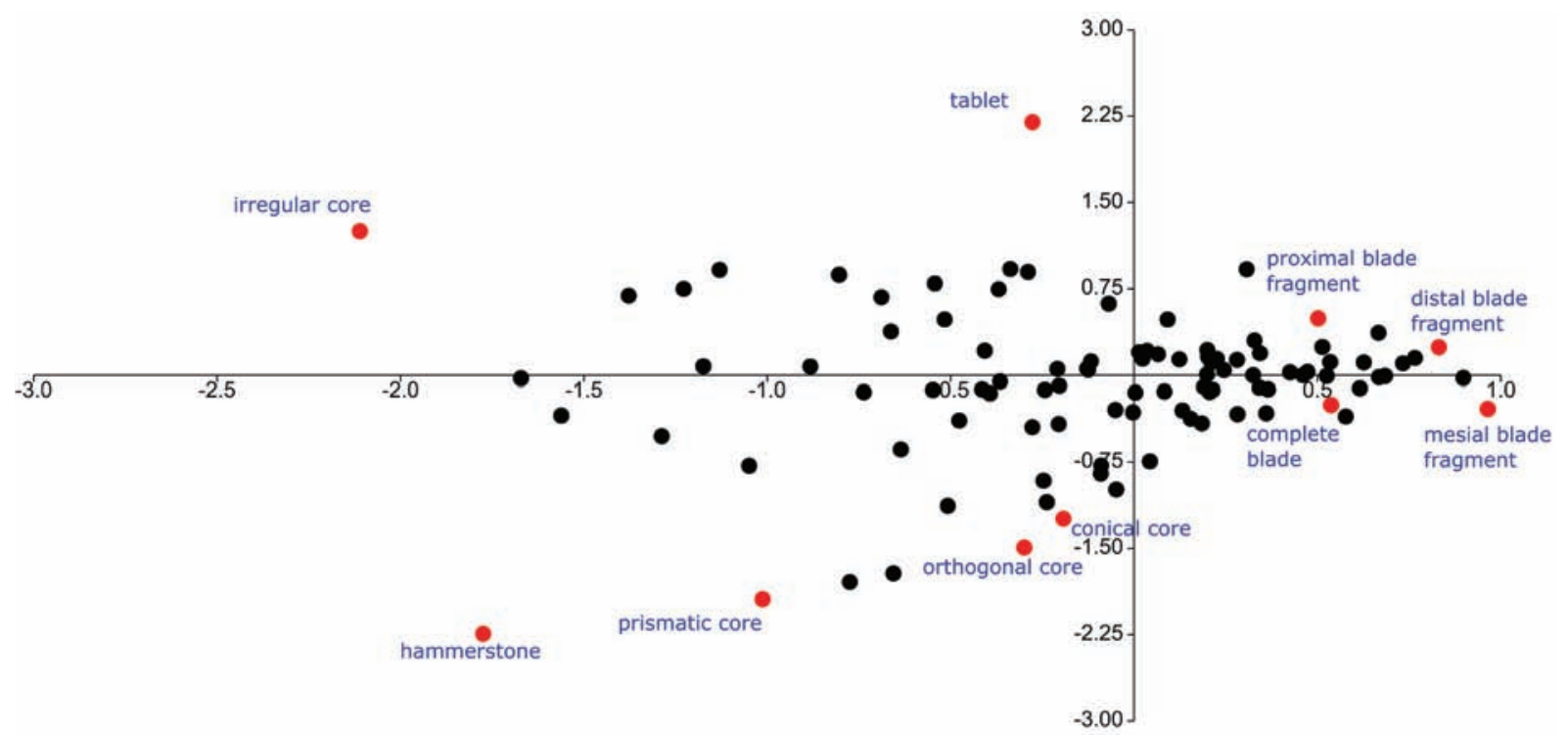

Fig. 7. Correspondence analysis of the detailed technological categories of Type 1 limnosilicite and the different features (without flakes). 
activities, activity zones. As far as the find distribution does not allow a clear classification, it seems that these zones did not have a special role or function, thus their flexible utilization is rather probable.

Another interesting result came up when analyzing the features with larger assemblages in combined correspondence analysis. The result was complimentary when projecting onto the settlement surface, regarding that the three main types of raw materials are in inverse proportionality with each other. Conducting a similar analysis on the technological categories and retouched types resulted in a similar, not too definitive but apparent, complex phenomenon. In other words, fine differences among the assemblages can reflect on the one hand the dynamism of the different activity zones; on the other hand, they encircle large, connected territories. Between these two layers lies the middle level of the homogenous smaller groups, which are characterized by periodic but varied activities. To sum up the different raw materials, technological categories and retouched types form a unified chipped stone assemblage on the settlement, but having a closer look makes it really clear how organic this system is.

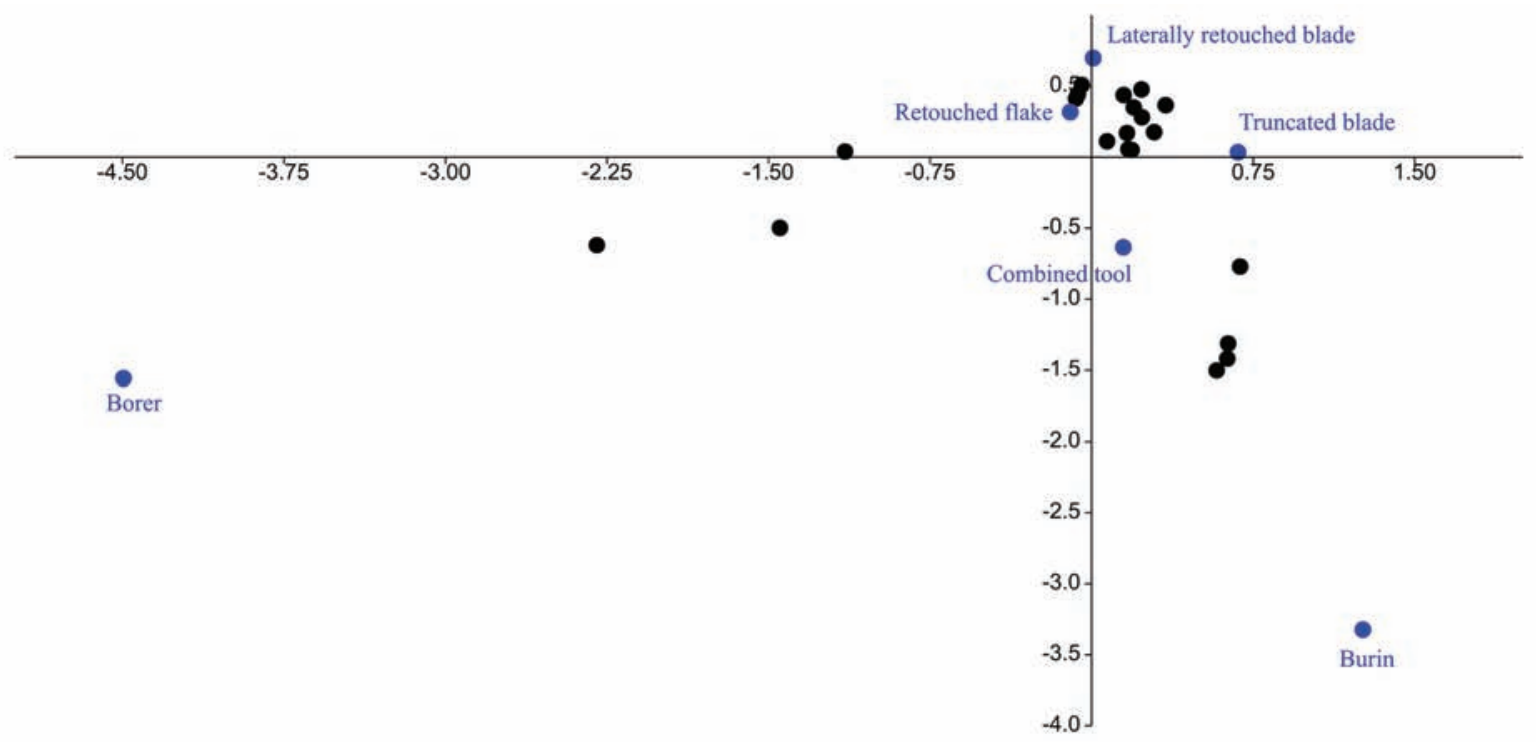

Fig. 8. Correspondence analysis of the retouched tools made of Type 1 limnosilicite and the different features (without end-scrapers).

Focusing on the tell part of the settlement, this process can be visualized more closely, however in a much less scale (Fig. 9). The assemblages that belong to the two buildings and to the pit differed from each other both quantitatively and qualitatively (Figs 10, 11). Not just the distribution of the different raw materials, but the technological categories and partly the retouched types represent a diversified picture among the analyzed assemblages. Inside each of the buildings, the floor level was nearly empty, thus the scene of the everyday life barely presented any object to observe. Below this level many more finds could have been found, concluding that floor refurbishment or infilling of building trenches raised the possibility of garbage or dump infiltration. This means that tools and waste could have accumulated in and around a specific building, generally resulting in a homogenous distribution on a larger scale in the end. However, thanks to the applied, more accurate technological and metrical means there are no basic differences between the above-mentioned assemblages, they represent complementarily the same tool-making tradition. 


\section{Temporality}

It is very important to bear in mind the different time-scales and temporalities when recording any change in the archaeological material of a specific society. This idea has been already introduced in the case of Polgár-Csőszhalom, because the two settlement parts, the tell and the horizontal settlement showed activities in a different rhythm and cycle through time. ${ }^{25}$ The reconstruction of site history and chronology can aid such a multi-scalar analysis, however, the work is far from done at this point. Investigating different temporalities means periodicity, and thus the life cycle of objects and features must be taken into account also. ${ }^{26}$ Moreover, a specific agent can transmit its effect much longer than researchers could imagine. A building, a pit, a vessel or a stone tool do not exist in just a single moment, but it can define a landscape, a society, a household or a single person through decades or even longer. ${ }^{27}$ So time interval and periodicity of an object or a feature is as important as their mere position in the event history, because chronology is only a tool to answer questions that point way beyond.

The outcome of the evaluation of the six chosen features with AMS dates from the horizontal settlement is the lack of any clear trend or any change in the chipped stone assemblage in a longer term (Figs 12-15). Neither the applied raw materials nor their ratio has changed, which could be interpreted as a temporal shift in any aspect. From the beginning, it seems that raw materials from the northern part of the Tokaj Mountains dominate the whole assemblage. In contrast, the Mezőzombor type from the southern part of the Tokaj Mountains plays only a minor part during the full lifetime of the settlement. However, obsidian of the same origin showed a more dynamic variability. As for the distant raw materials, their ratio was homogenously low

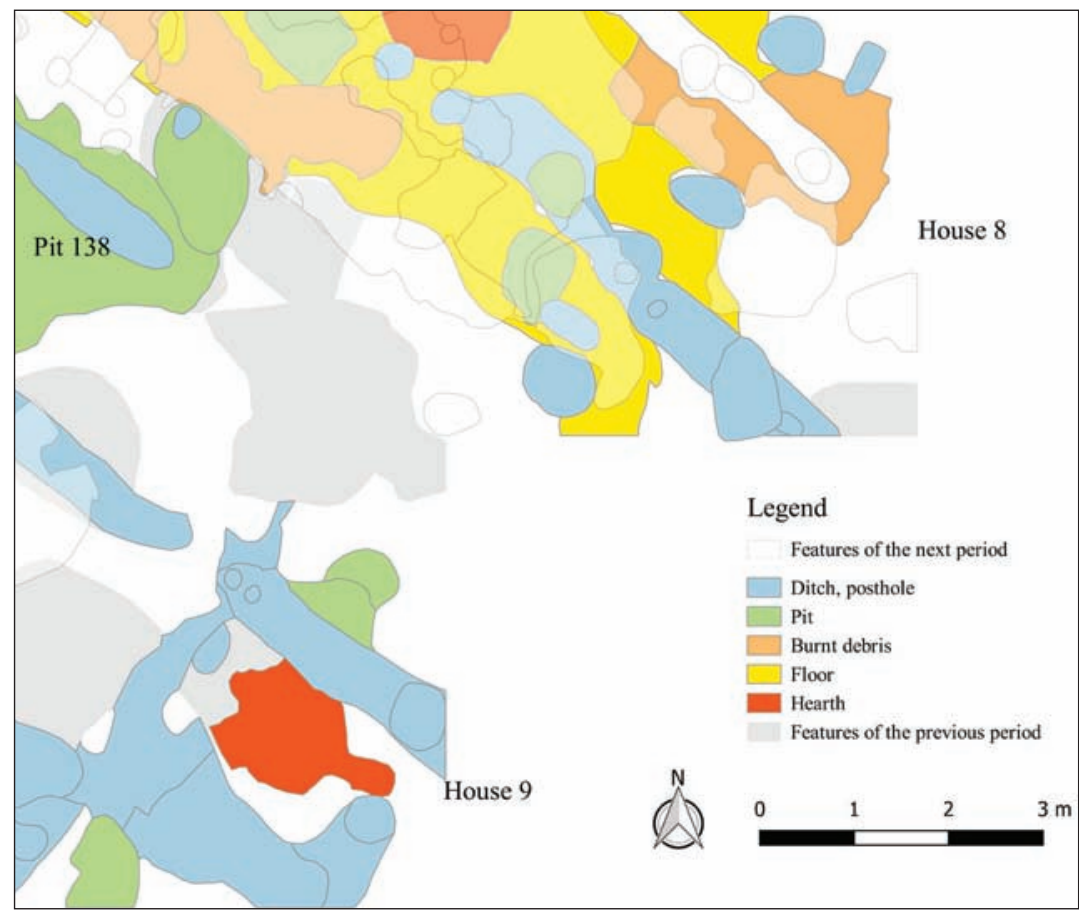

Fig. 9. Situation of Building 8, 9 and Pit 138 on the third level of Trench 4 at the tell. (Graphic: G. Mesterházy, design: N. Faragó). in every respective feature. The technological analysis resulted in a similar way: there is no statistically significant difference among the different features neither in a specific raw material, nor between different raw materials. The amount of end-scrapers in the group of retouched tools is so dominant that it makes the relationship between other types insignificant. Generally, the most important observation can be connected to two specific, neighboring features, because the greatest difference between the two

25 RACZKy et al. 2015.

26 BAIley 1981; LucAs 2005; CAMPBell 2012.

27 INGOLD 1993. 


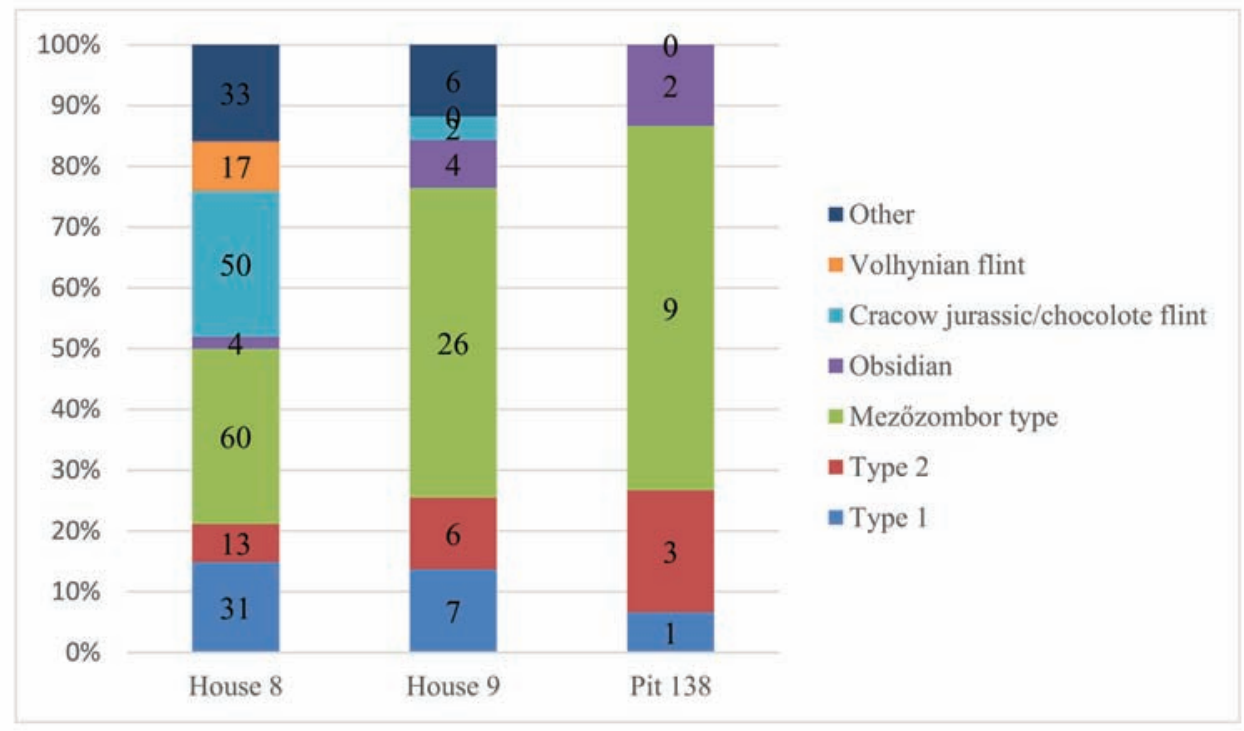

Fig. 10. Overall distribution of the raw materials coming from Building 8, 9 and Pit 138 (pcs).

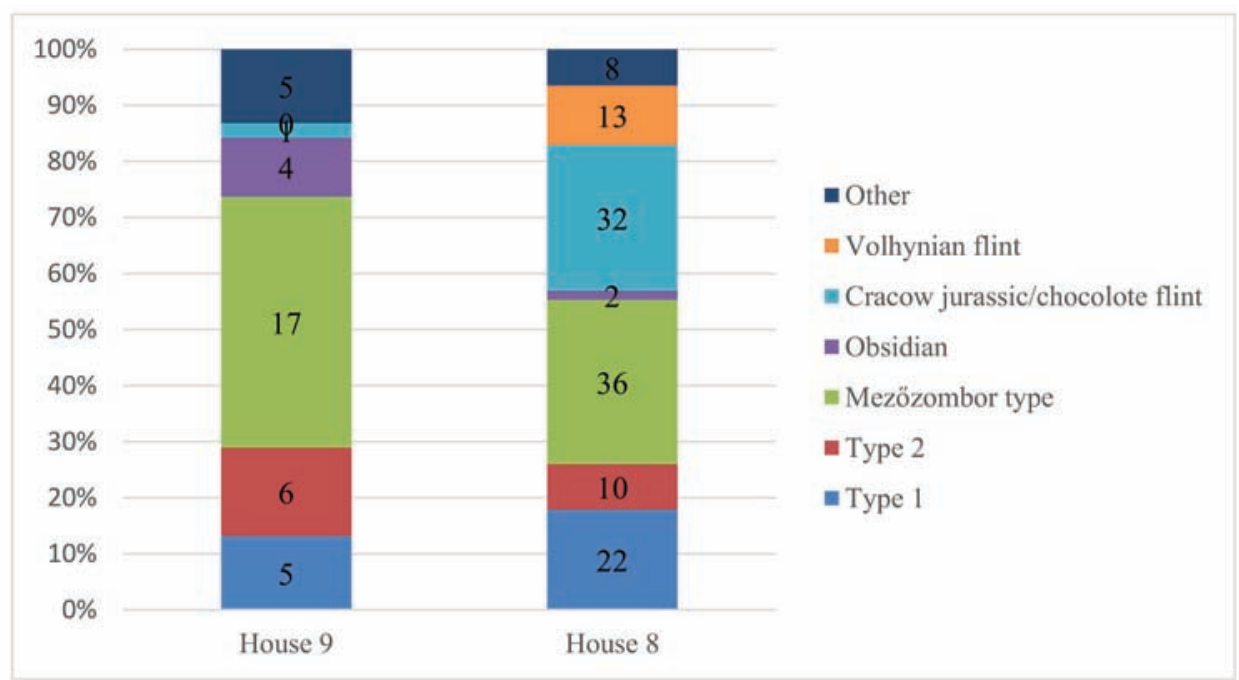

Fig. 11. Overall distribution of the raw materials coming from below the floor level of Building 8, 9 (pcs).

assemblages was recorded between them. Meanwhile, these two sets of finds complemented each other and represented the complete stone tool making tradition at this settlement. In this sense, although there are no long term trends, small-scale differences can be detected on the level of the everyday life in the short term.

The tell settlement part gave an opportunity to investigate long term, continuous processes, and in this sense a clear trend became apparent (Figs 16-21). As time passed by, distant, socalled exotic raw materials became more and more frequent. However, it is possible that this observation can be associated with the growing amount of orthogonal and conical cores. A clear expansion of types was observed among the retouched tools, although it was more obvious in the third excavation trench. Considering the middle-level temporal cycles, a definine, repetitive pattern was apparent among the single layers, whose ingredients were nearly identical. Analyzing the two trenches in this sense, they revealed the most significant difference, 


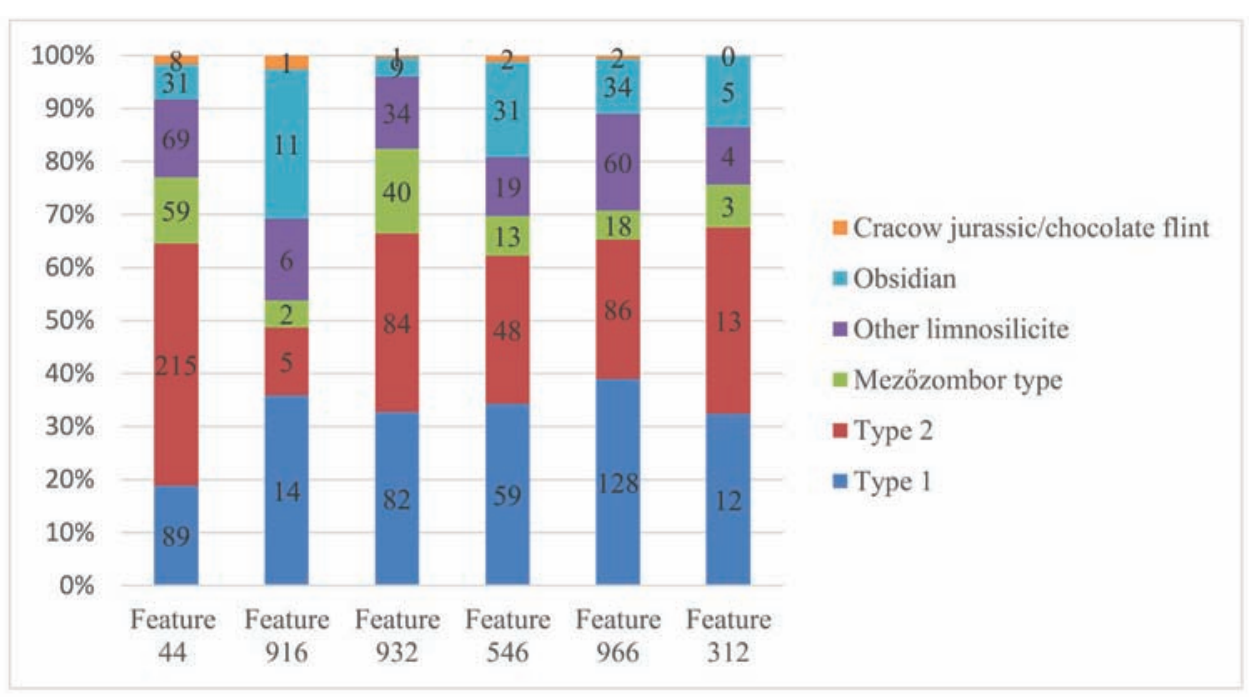

Fig. 12. Overall distribution of raw materials coming from the six chosen features at the flat settlement.

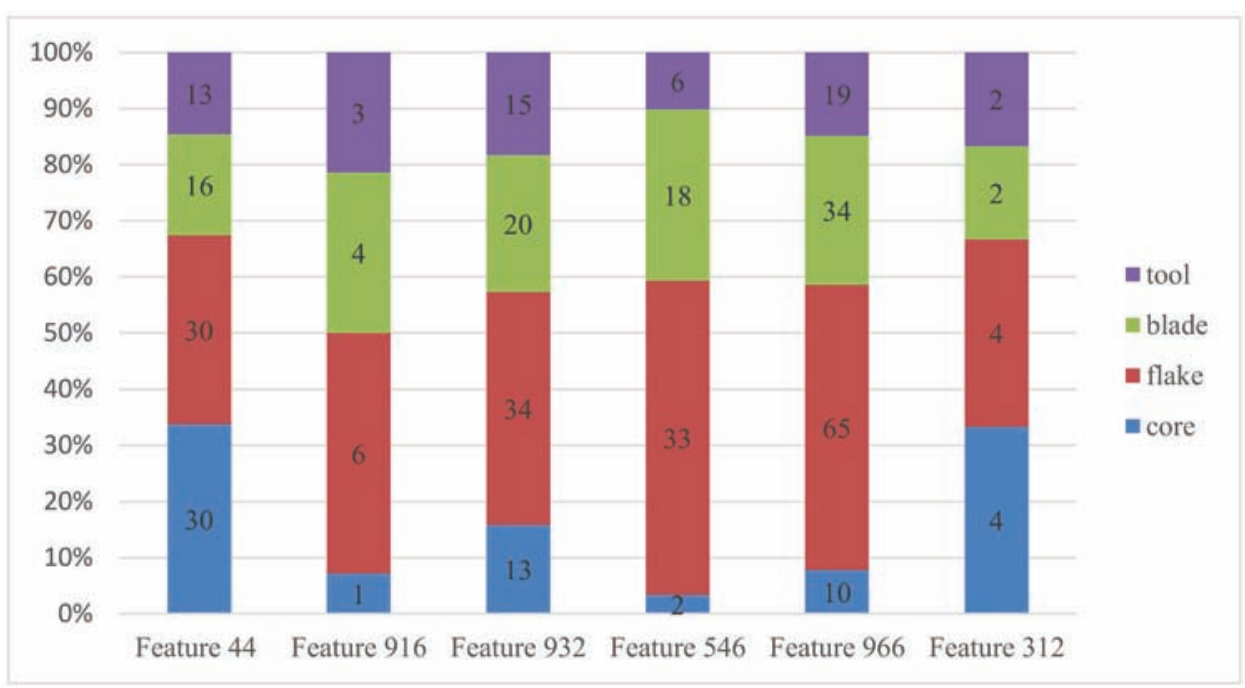

Fig. 13. Distribution of technological categories of Type 1 limnosilicites coming from the six chosen features of the flat settlement.

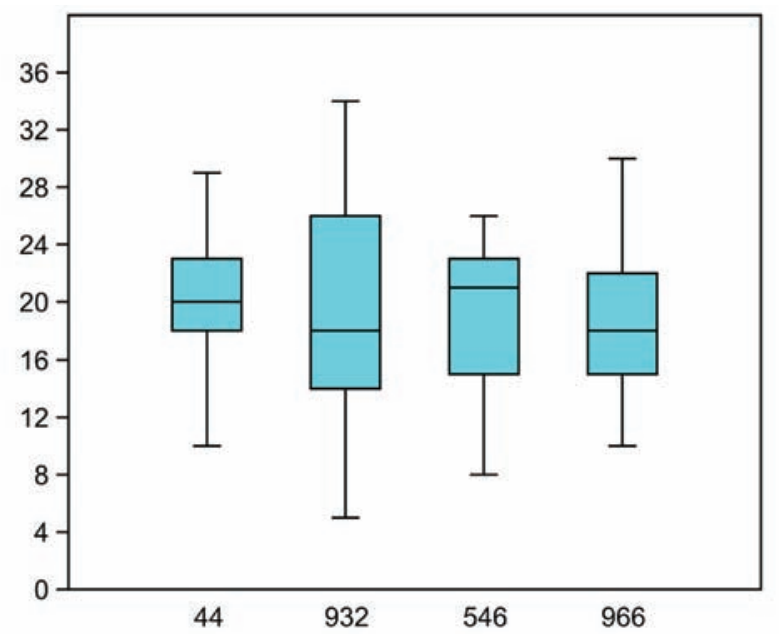

Fig. 14. Width of blades and blade fragments made of Type 1 limnosilicite coming from the different features. 


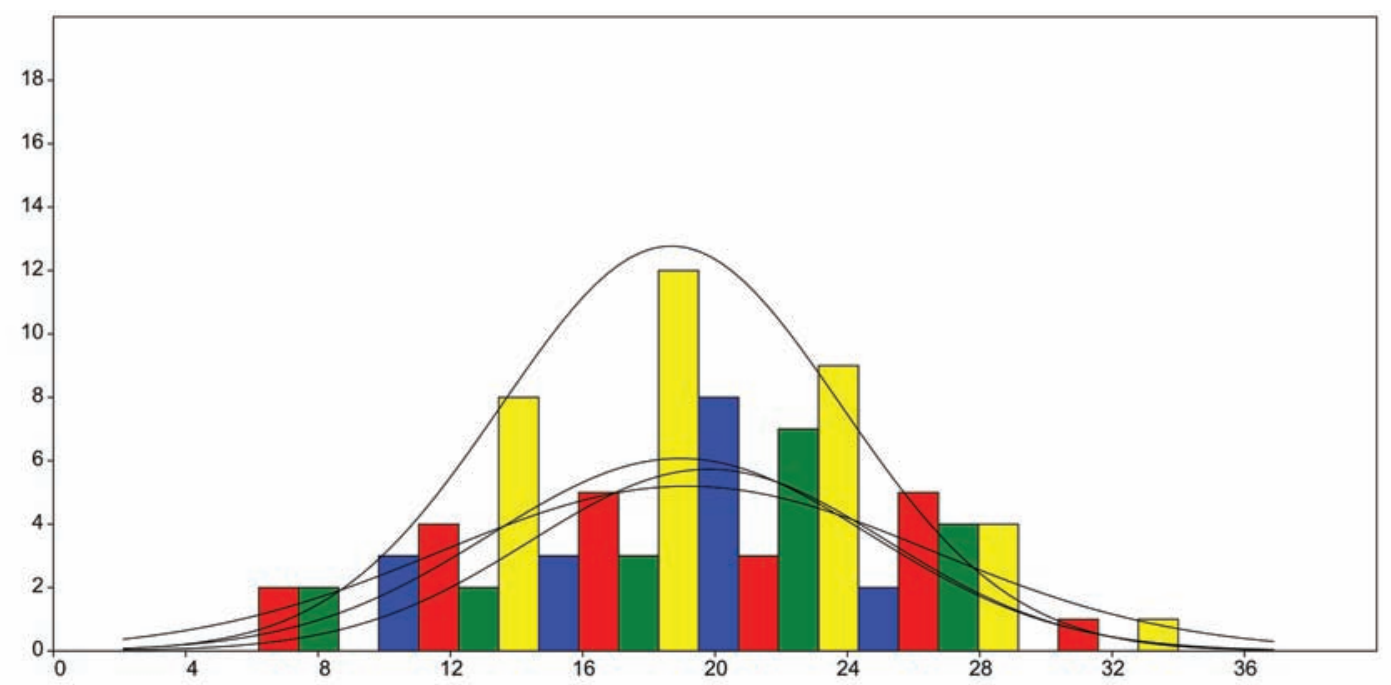

Fig. 15. Width of blades and blade fragments made of Type 1 limnosilicite coming from the different features (blue - feature 44; red - feature 932; green - 546; yellow - 966).

because the largest assemblages in the third trench were connected to the layers with significant fillings without any building structures, respectively the $1^{\text {st }}, 4^{\text {th }}, 5^{\text {th }}$, and $8^{\text {th }}$. On the contrary, the repeating pattern of the fourth trench reflected the richness of the $3^{\text {rd }}$ and $7^{\text {th }}$ layers, which was affected by house constructions. However, the largest filling layer that was present in the two trenches showed abundancy in both cases.

\section{Symbols, rites}

Human neuroanatomical attributes contributed to the cognitive and linguistic abilities in a complex way, which was the basis for abstract thinking and self-expression, thus resulted in the birth of advanced social structures and relationships. ${ }^{28}$ During this process, it was necessary for the symbols to transform into physical objects, and later into events, movements and acts, in other words to become rites. In the end, these symbols and rites act interactively with the members of the society while becoming the solid ground for a common worldview or even a religion. ${ }^{29}$ The archaeological imprint of such a complex phenomenon, which is a process and a result at the same time, can be very fragile. ${ }^{30}$ However, archaeologists can research rites from three different aspects: firstly, rites that focused on single persons or smaller groups and served during the transformation of the involved people from one social state to another can be analyzed. Secondly, grand and monumental rites can be also analyzed, which served as a medium in strengthening the inner cohesion and self-definition of the whole community, and which can be named as religious, collective rites. Thirdly, domestic rites the purpose of which was to provide a channel to the supernatural during everyday life can be also taken into account. It can be hardly differentiated from the common practice, thus being definitive at the lowest level of the social life of a community. These categories are not clean-cut, it is obvious that in a community the ancient superstitions and

30 Osborne 2004; Fogelin 2007; Garrow 2012; McNiven 2013. 
practices formed the basis, and merged with initiation, wedding and funeral ceremonies into a coherent cosmology, which acts as a cause and effect at the end.

Chipped stones are not so frequent in the funeral rite; altogether only 20 graves presented such grave good from the 123 graves at the horizontal settlement of Polgár-Csőszhalom (Figs $22,23)$. In five cases it was associated with women and in two cases with children. Generally, two or three pieces occurred per grave, but this frequency is higher in male burials. The most pieces came from Grave 489 (11 pcs) and Grave 406 (7 pcs) (Fig. 24). In contrast, female burials never contain more than two pieces, the two children had only one piece each. The number of the chipped stones is in inverse proportionality with the age of the deceased, which means that males deceased younger than 40 were accompanied by more than two pieces, while women of the same age had a maximum of two pieces.

Distant raw material occurred in only three cases, typically in graves where young males had two or three further pieces also. Sex and age showed no correspondence with any raw material. An interesting and general attribute of the respective chipped stones is the patina, which, in some cases, made the raw material definition difficult.

Among the technological categories, unretouched blades are the most numerous, while retouched tools are the second ones. On the contrary, almost no pieces of flakes or cores were placed in the graves. Moreover, there is no relationship between raw material types and technological categories in this sense.

According to the retouched pieces, the distribution of the various types is not so diversified, the whole assemblage is very homogenous. One-third of the pieces belong to the trapezes, half of them are truncated blade, and the rest is end-scraper. Trapezes and truncated blades were associated with men exclusively, who were deceased in the age of 30 or 40 . The only three end-scrapers were distributed among two women and one single man.

Among the 19 graves of the tell, only one contained chipped stones, which was actually a cenotaph. There was no core deposited in the burials of the horizontal settlement, but this cenotaph had one, moreover, a well-elaborated end-scraper belonged to this small assemblage also. Common characteristics of the two settlement parts are the general presence of the patina on the chipped grave goods.

Continuing with other structured depositions, chipped stones in post holes are not so frequent at the horizontal settlement. Apart from its situation, the obsidian core counts as a unique find, because there is no other core in such size and form (Fig. 25). This object does not reflect the general way this raw material appears at the settlement, since generally, obsidian cores and debitage products are much smaller and the connecting technological know-how needed a different attitude.

Chipped stones coming from wells or well-like hollows at the lowermost part of the pits are not so frequent either. The pieces evaluated in this dissertation are rather the exception and not the rule. Well 272 contained 11 fragments (Fig. 26), while Well 966 contained 12 chipped stones $^{31}$. It seems that neither the raw material, nor the technological category, nor typology was important during the choice of the accessories of the deposition rite. However, apparent similarities between the two equally homogenous assemblages suggest a conscious selection.

31 SЕво̋к et al. 2013. 


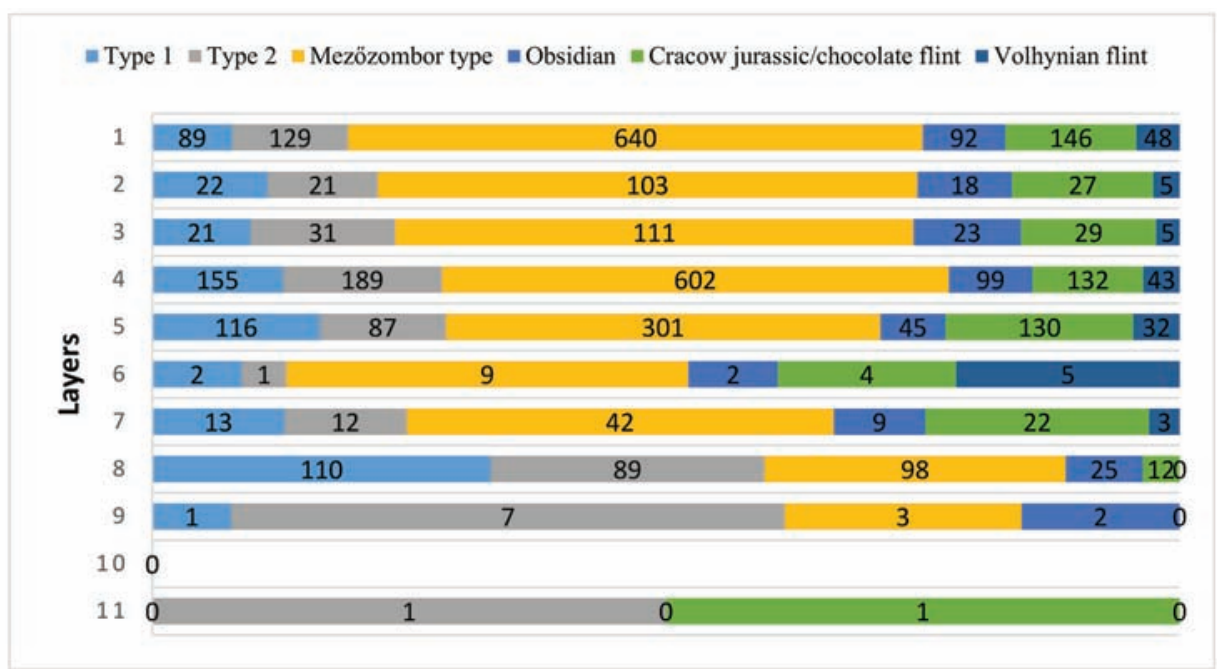

Fig. 16. Distribution of different raw materials in Trench 3 at the tell.

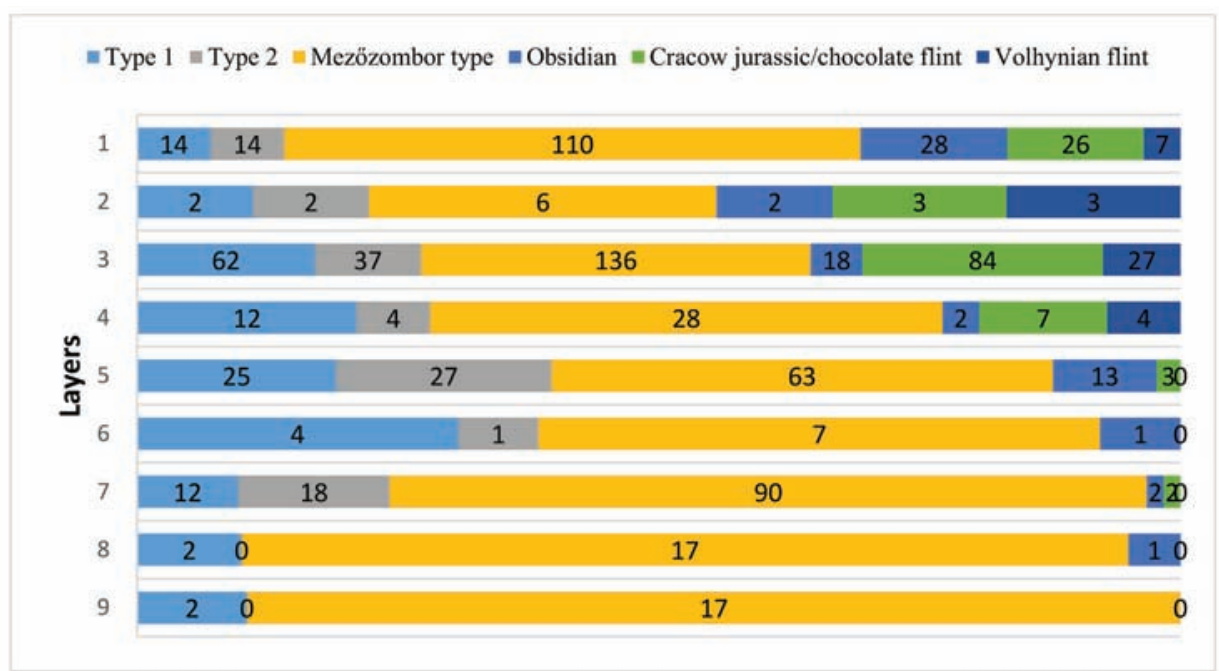

Fig. 17. Distribution of different raw materials in Trench 4 at the tell.

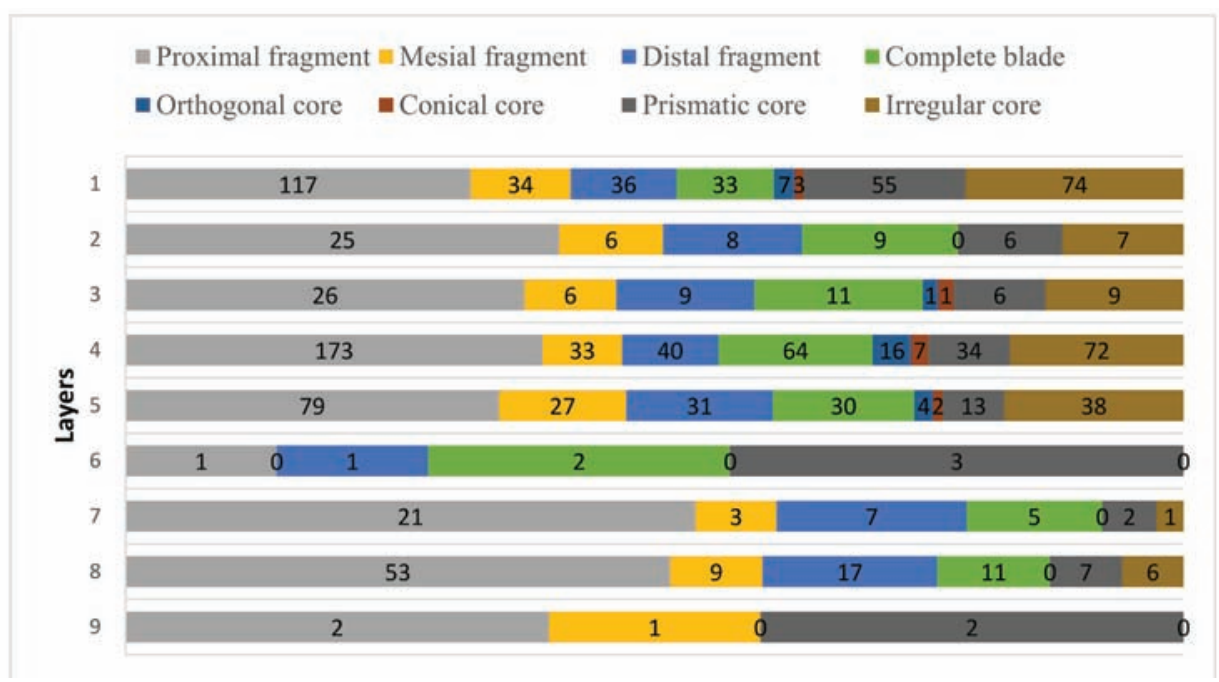

Fig. 18. Distribution of the overall technological categories in Trench 3 at the tell (without flakes, tablets and hammerstones). 


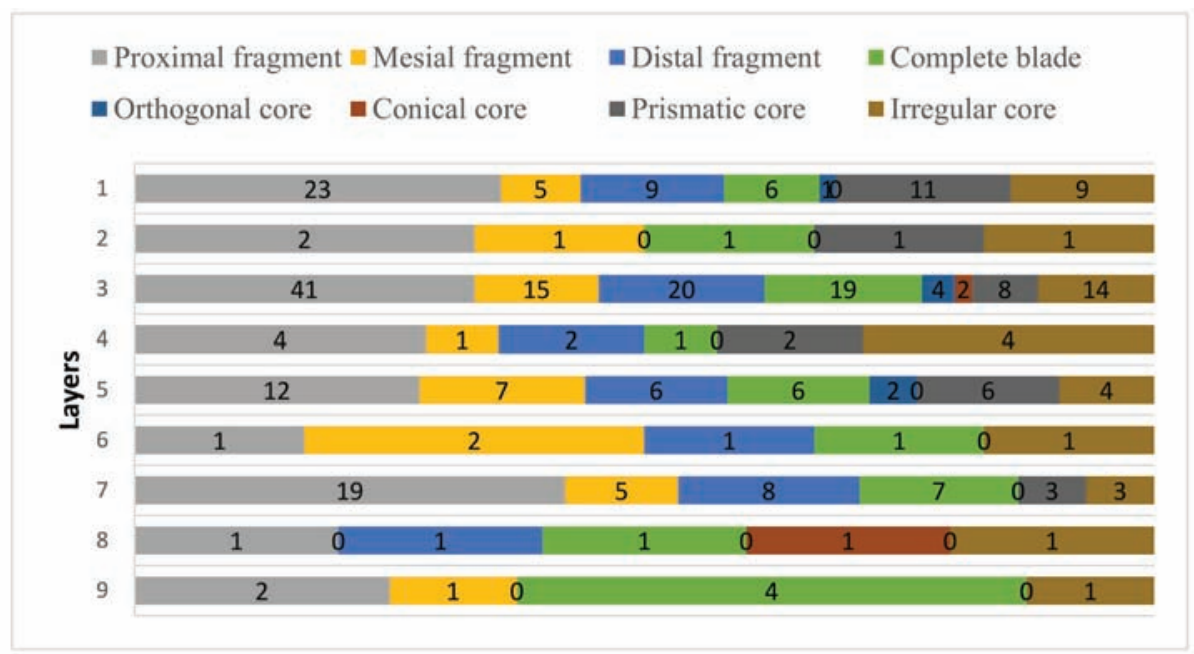

Fig. 19. Distribution of the overall technological categories in Trench 4 at the tell (without flakes, tablets and hammerstones).

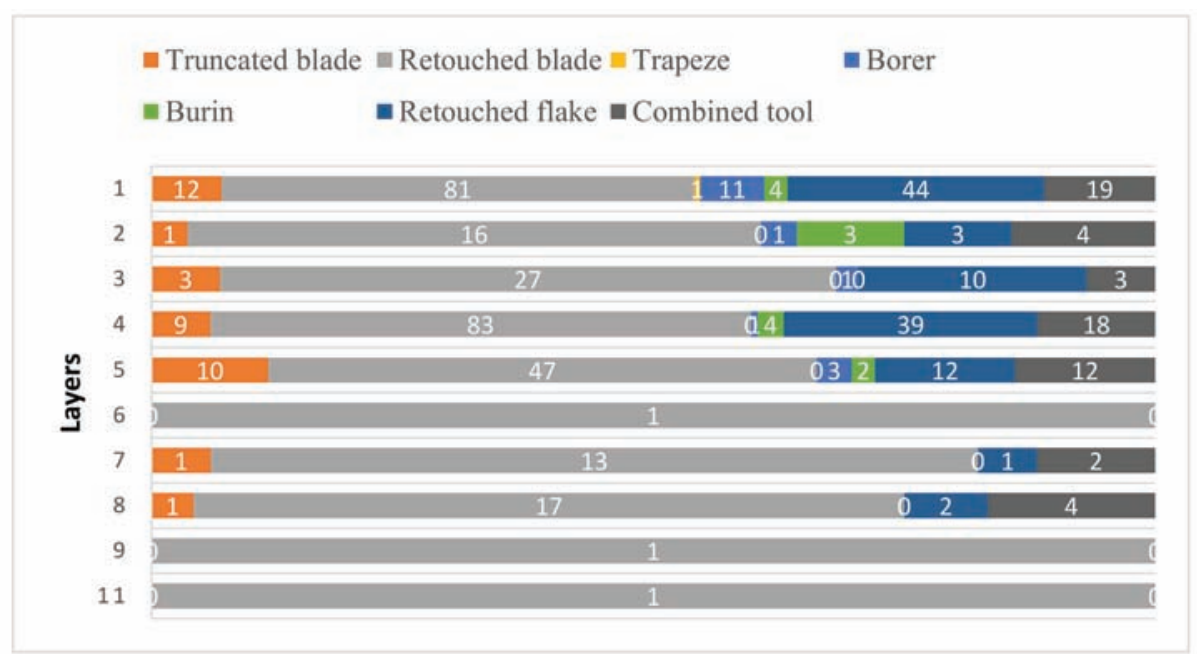

Fig. 20. Distribution of the retouched pieces in Trench 3 at the tell (without end-scrapers).

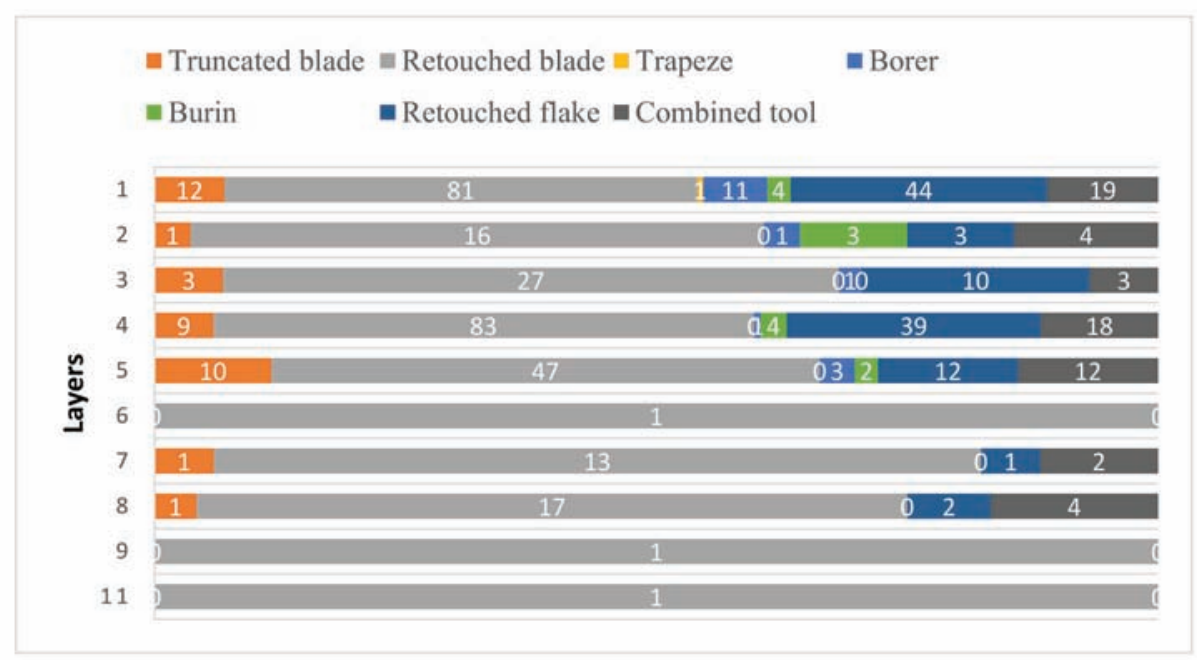

Fig. 21. Distribution of the retouched pieces in Trench 4 at the tell (without end-scrapers and splintered pieces). 
On the contrary, the tell presented many knapped pieces in structured depositions: the assemblage at the floor of House 9 is one of them. It consisted of 4 chipped stones, among which one was made of chocolate flint and three were made of Mezőzombor type. One hammerstone, two blade fragments, and one flake can be mentioned from a technological perspective. There were no retouched pieces, but two polished axes from two different raw materials completed the picture.

Among the settlement features of the horizontal settlement, examples are extremely rare where any direct burning effect can be detected. The only oven, its remains, and a clear burnt rubble layer were observed during the excavation of Pit 705. In most aspects, the chipped material coming from this structure was similar to the ordinary settlement fillings deposited above. This stratigraphic unit, number 1625 represented only one Mezőzombor type, while limnosilicites other than the main types were relatively frequent. Raw materials from a greater distance, first of all, Cracow Jurassic flint were equally present in both the upper and the lower part of this structure. Another characteristic feature was the high ratio of the cores in the burned rubble, but the oven itself and a layer with ash remains beside showed only 7 pieces.

Continuing with further features with burned remains, houses destroyed by fire were present only at the tell part of the settlement, at least in 11 cases. The structure with two distinct stories from the lowest part of the mound was chosen for further analysis ${ }^{32}$. The middle part of the rubble was the most abundant in chipped material, while the upper and lower parts represented equal numbers. The raw material distribution seemed very homogenous, most of the time the pieces were connected to the Mezőzombor type, while distant raw materials were completely missing, and obsidian was present only at the uppermost part. The technological categories were distributed evenly also, but the two pieces of cores came to light from the top level. Retouched pieces were made of Mezőzombor type too, interestingly apart from the end-scrapers truncated blades, and retouched blades were present in a fair number.

\section{Taphonomy}

Paleontology-archaeozoology and archaeology both reached a point in the 1970s where the site formation process appeared among the many variables in the equation of the archaeological interpretation. The main difference between the two disciplines is that excavation technique as a bias of the result has been taken into account seriously in archaeozoology for decades. ${ }^{33}$

Stratigraphic feature 205 gave us the possibility to compare the excavation methods of planned excavations with the methods of rescue excavations, at least partly (Figs 27, 28). After being excavated by the latter means, and archaeological finds were revealed, the whole infilling was screened, and further finds were separated from it. So the main difference between the two assemblages would be connected directly with the applied excavation strategies. The results partly verified the preliminary expectations, as the overall number almost grew by twenty times. It is also obvious that there is a greater chance to find smaller chipped stones by finer excavating methods. In this case, the average size of the pieces decreased by 1-1.5 centimeters. This kind of quantitative difference raises the question what influence this result makes on the two assemblages, and on which variables this will have an effect.

32 FARAGÓ 2017.

33 Payne 1972; Bartosiewicz 1988; Thomas - Zapata 2017. 
Considering the raw material distribution, the most significant difference is that while there was not one obsidian piece before the screening, the ratio of this raw material reached $15 \%$ in the overall assemblage. The rest of the pieces are equally made of different raw materials, making their distribution well-balanced. Distant raw materials became less significant compared to the situation before the sieving, although there was some Cracow Jurassic flint in this assemblage also.

\begin{tabular}{|c|c|c|c|c|c|c|c|}
\hline $\begin{array}{l}\text { Obj. } \\
\text { no. }\end{array}$ & $\begin{array}{l}\text { Str. } \\
\text { no. }\end{array}$ & Age & Sex & Phase & Polished tool & Position & $\begin{array}{l}\text { Chipped } \\
\text { stone no. }\end{array}$ \\
\hline 105 & 119 & $23-39$ & male & - & - & - & 4 \\
\hline 126 & 237 & $9-10$ & inf. & - & - & - & 1 \\
\hline 362 & 703 & $31-35$ & female & 3 & $x$ & - & 2 \\
\hline 365 & 709 & $31-40$ & male & - & - & - & 3 \\
\hline 406 & 789 & $34-38$ & male & 3 & $x$ & neck, right ankle & 7 \\
\hline 429 & 827 & symbolic & - & - & $\times$ & - & 5 \\
\hline 472 & 963 & $39-43$ & male & - & $x$ & left arm & 1 \\
\hline 486 & 993 & $31-40$ & male & - & $x$ & right pelvis & 4 \\
\hline 489 & 994 & $\begin{array}{l}\text { adultus- } \\
\text { maturus }\end{array}$ & male & - & $x$ & left arm, left knee & 11 \\
\hline 493 & 998 & $3-4$ & inf. & 4 & - & - & 1 \\
\hline 612 & 1327 & $49-55$ & female & - & - & skull and beside hands & 1 \\
\hline 619 & 1352 & $31-40$ & female & 4 & - & right knee & 2 \\
\hline 630 & 1387 & $24-28$ & male & - & $x$ & $\begin{array}{c}\text { left arm, left hand, left knee, } \\
\text { vertebrae }\end{array}$ & 4 \\
\hline 642 & 1424 & $47-51$ & male & - & $x$ & left hand, vertebrae & 2 \\
\hline 785 & 1734 & $63-70$ & male & 4 & $\times$ & ankle & 2 \\
\hline 886 & 1911 & $61-70$ & female & 2 & - & left foot & 1 \\
\hline 902 & 1847 & $35-39$ & female & - & - & face & 2 \\
\hline 936 & 2049 & $54-60$ & male & 3 & $x$ & humerus & 1 \\
\hline 1083 & 2359 & $29-33$ & male & 4 & $x$ & - & 3 \\
\hline 1165 & 2555 & - & male & 3 & - & right shoulder & 1 \\
\hline
\end{tabular}

Fig. 22. Lithics in the graves at the flat settlement of Polgár-Csőszhalom (for the results of the anthropological analysis see ZofFmann 2012).

Generally, the distribution of the technical categories changed as well, the ratio of the cores decreased from the previous $15 \%$ to $3 \%$. The number of retouched pieces decreased similarly, it changed from $20 \%$ to $10 \%$. Among the ratio of the unretouched flakes and blades, the latter one increased more significantly, the former $25 \%$ became $40 \%$. Considering the different raw materials and their technological categories one by one, their overall diverse character became more homogenous after the sieving. The more detailed technological attributes, like the talons and preparations of the debitage products, the knapping angles, or the different core strategies did not show any correlation with the respective raw materials either. The metric 
analysis of the unretouched debitage products suggests a homogenized stone industry, which is apparent among the limnosilicite variants and the distant sources also (Figs 29, 30). According to the width of the blades and blade fragments, only the obsidian and type 2 limnosilicite differ from the average in a statistically significant way. The average length of the complete blades is also homogenous, with the exception of the obsidian pieces that are generally smaller. The retouched pieces coming from the sieved assemblage did not affect the general picture, as the abundance of the end-scrapers is obvious in every aspect. Other types, like truncated blades, laterally retouched blades and retouched flakes are well-balanced compared to each other, thus there is no specialization according to the raw materials. Interestingly, several types, like burins, borers, trapezes became visible after the sieving, although only in minor quantity. The first two types are sporadically present at the settlement, but trapezes are absolutely unique in Polgár-Csőszhalom.

\begin{tabular}{|c|c|c|c|c|c|c|c|c|c|c|c|c|c|c|c|c|}
\hline \multirow[b]{2}{*}{$\begin{array}{c}\text { Obj. } \\
\text { no. }\end{array}$} & \multirow[b]{2}{*}{$\begin{array}{c}\text { Str. } \\
\text { no. }\end{array}$} & \multirow[b]{2}{*}{ Age } & \multirow[b]{2}{*}{ Sex } & \multicolumn{4}{|c|}{ Raw material } & \multicolumn{5}{|c|}{ Technology } & \multicolumn{4}{|c|}{ Typology } \\
\hline & & & & 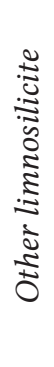 & 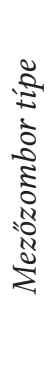 & 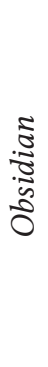 & 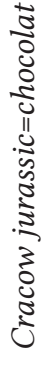 & نे & $\frac{\frac{\Xi}{0}}{n}$ & 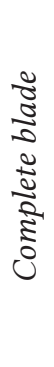 & 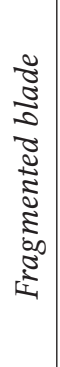 & $\overrightarrow{8}$ & 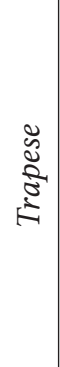 & 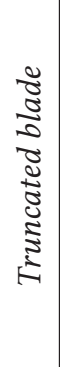 & 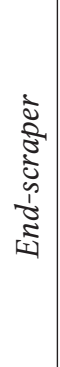 & 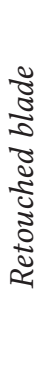 \\
\hline 105 & 119 & $23-39$ & male & 3 & - & - & 1 & - & - & 1 & - & 3 & 1 & 2 & - & - \\
\hline 126 & 237 & $9-10$ & inf. & - & 1 & - & - & - & - & 1 & - & - & - & - & - & - \\
\hline 362 & 703 & $31-35$ & female & 2 & - & - & - & - & 1 & - & - & 1 & - & - & 1 & - \\
\hline 365 & 709 & $31-40$ & male & 2 & - & - & 1 & - & - & 1 & - & 2 & 1 & 1 & - & - \\
\hline 406 & 789 & $34-38$ & male & 6 & - & 1 & - & - & - & - & 4 & 3 & 2 & 1 & - & - \\
\hline 429 & 827 & symbolic & - & 5 & - & - & - & - & - & - & 5 & - & - & - & - & - \\
\hline 472 & 963 & $39-43$ & male & 1 & - & - & - & - & - & - & - & 1 & - & 1 & - & - \\
\hline 486 & 993 & $31-40$ & male & 4 & - & - & - & - & - & 1 & - & 3 & 2 & 1 & - & - \\
\hline 489 & 994 & adultus-maturus & male & 9 & 1 & 1 & - & - & - & 1 & 7 & 3 & 1 & 2 & - & - \\
\hline 493 & 998 & $3-4$ & inf. & 1 & - & - & - & - & - & - & - & 1 & - & - & - & 1 \\
\hline 612 & 1327 & $49-55$ & female & & 1 & - & - & - & - & - & 1 & - & - & - & - & - \\
\hline 619 & 1352 & $31-40$ & female & 1 & - & 1 & - & - & - & 1 & 1 & - & - & - & - & - \\
\hline 630 & 1387 & $24-28$ & male & 1 & 2 & - & 1 & - & - & - & 2 & 2 & - & 1 & 1 & - \\
\hline 886 & 1911 & $61-70$ & female & 1 & - & - & - & - & - & - & - & 1 & - & - & 1 & - \\
\hline 902 & 1847 & $35-39$ & female & - & - & 2 & - & - & - & 2 & - & - & - & - & - & - \\
\hline 936 & 2049 & $54-60$ & male & 1 & - & - & - & - & 1 & - & - & - & - & - & - & - \\
\hline 1083 & 2359 & 29-33 & male & 1 & - & 2 & - & - & - & - & 3 & - & - & - & - & - \\
\hline 1165 & 2555 & - & male & - & - & 1 & - & - & - & 1 & - & - & - & - & - & - \\
\hline
\end{tabular}

Fig. 23. Raw material, technology and typology of the lithics in the graves at the flat settlement of Polgár-Csőszhalom. (for the results of the anthropological analysis see ZoffMAN 2012). 


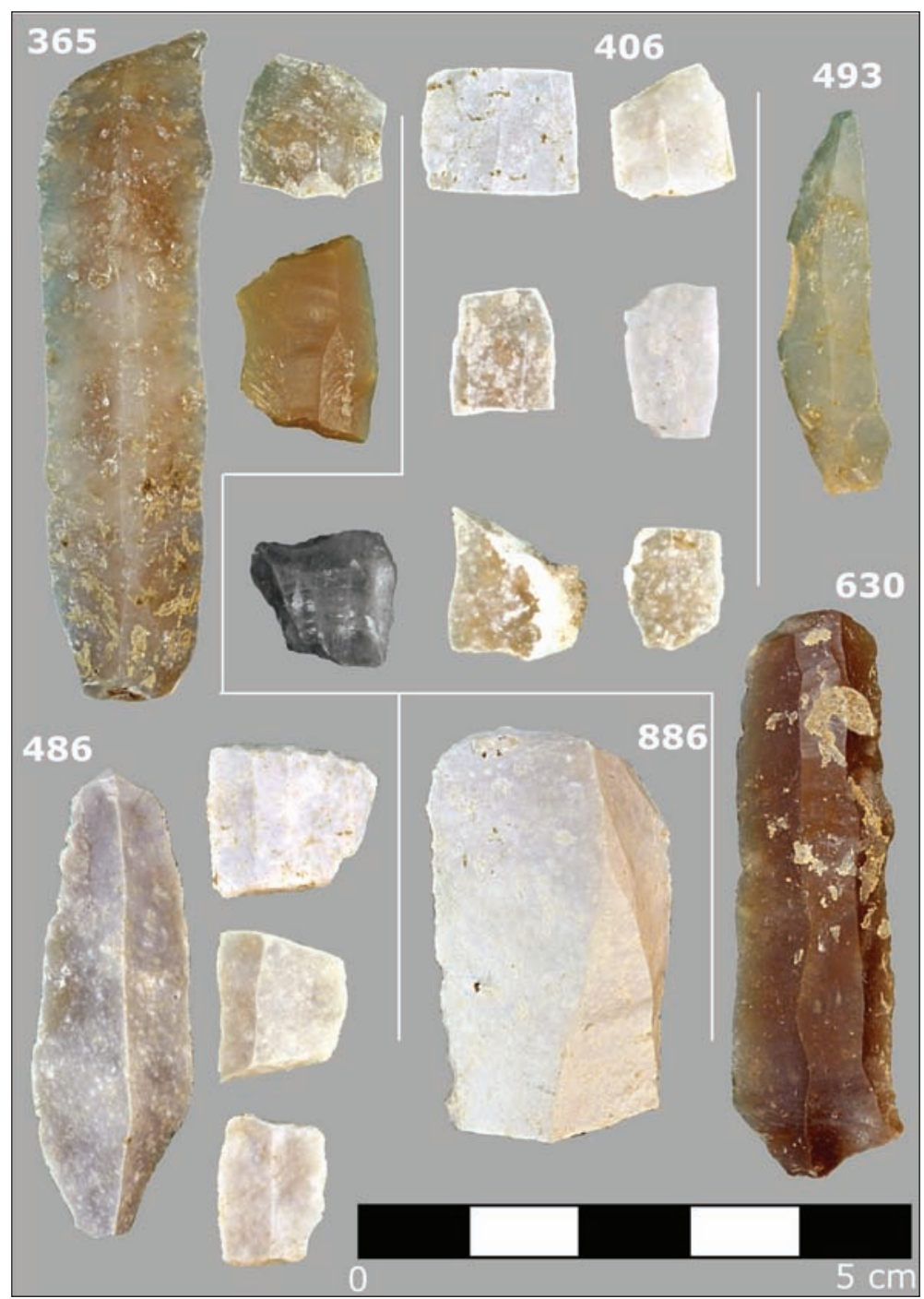

Fig. 24. Collection of lithics from six different graves at the flat settlement of Polgár-Csőszhalom.

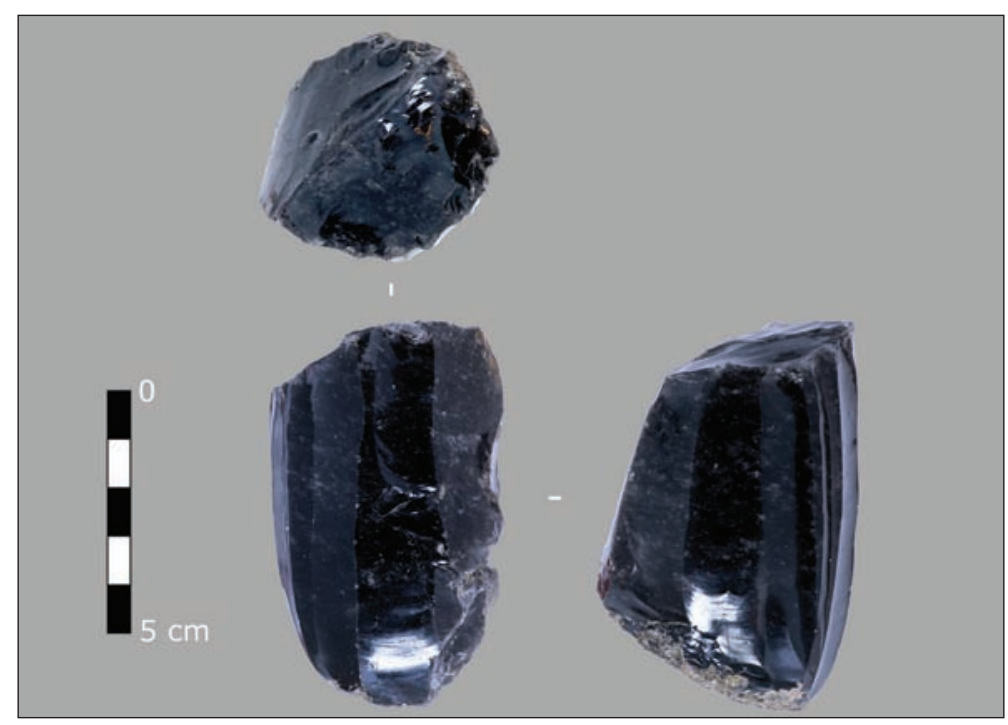

Fig. 25. Obsidian core from a posthole of House 998.

\section{Results and conclusion}

According to the above-mentioned results, the following model can be raised about the knapping activity of the onetime residents of Polgár-Csőszhalom. The majority of their raw material was originated from the Tokaj Mountains in a very homogenous form. Two consistent trends were detected in the ratio of the three main types of limnosilicites, which proves a centralized acquisition. It could mean either two distinct routes or two distinct sources. The knapping activity or at least its waste was focused on smaller activity zones defined by 4-7 buildings (Figs 31-34). These zones were located at a distance of $30-50$ meters from each other, and they consisted of smaller and larger assemblages. The physical limits of these zones were strict, and it is plausible that they were definitive for a very long time. The different activities encircled by these house groups represented all phases of the knapping process, but the debitage products tended to be focused, while the cores were distributed more evenly around the surface. The variability of the smaller assemblages could have indicated the individual activities repeated within a shorter time frame, while the larger assemblages could have reflected the activities conducted during decades and then created a homogenous pattern over large distances (Fig. 35). These larger assemblages 
served as a basis for the definition of the house groups: they are uniformly similar to each other, and they are far away from each other at the same time. In this sense, these house groups seem to be autonomous, and their self-sustainability is rather plausible. Distant raw materials, like Cracow Jurassic flint and Transdanubian radiolarite, are evenly distributed, especially when considering their low ratio, thus no peculiar role can be detected archaeologically beyond their economic aspect. Yet, the generally homogenous habit of the different zones might have

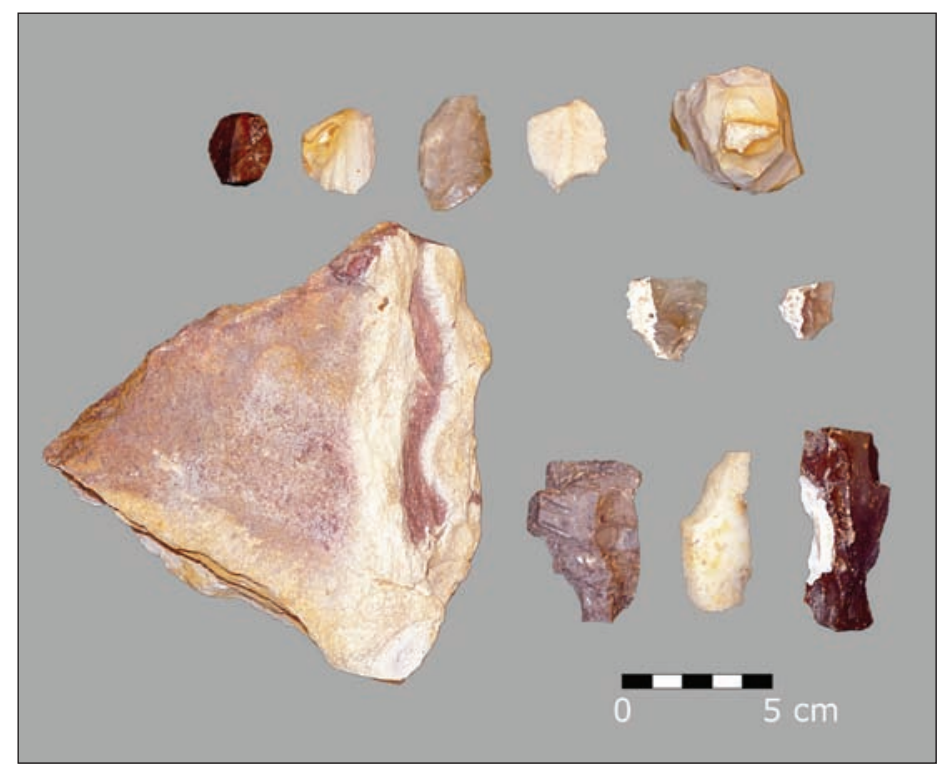

Fig. 26. Lithics from Well 272.

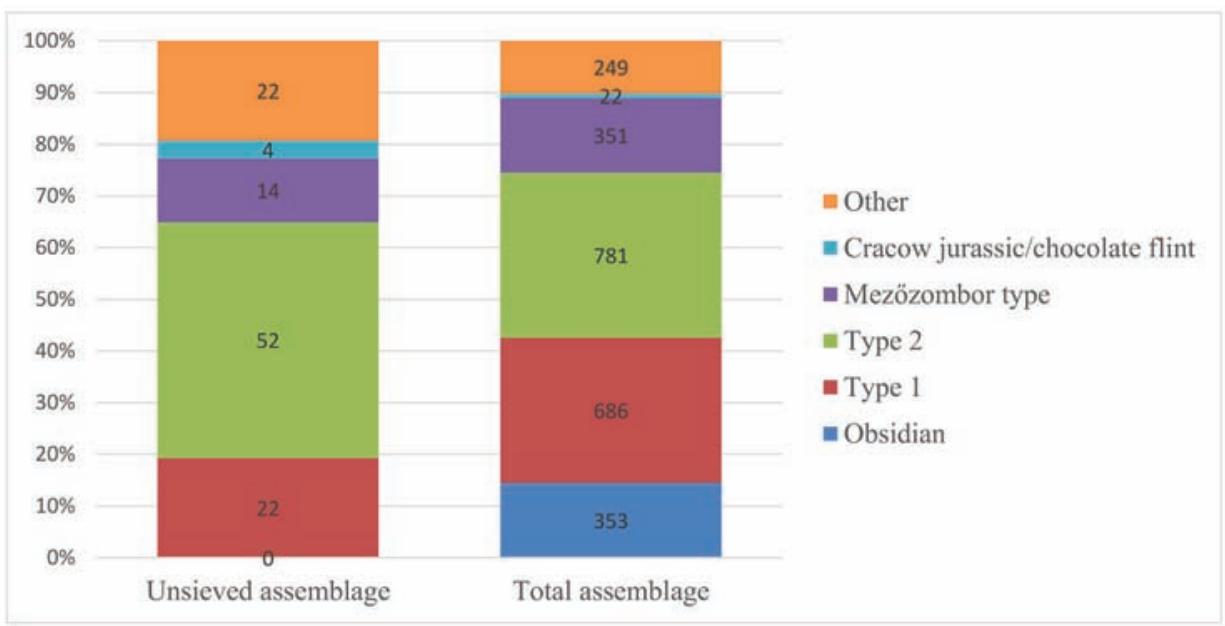

Fig. 27. Distribution of different raw materials from Feature 205 before and after sieving.

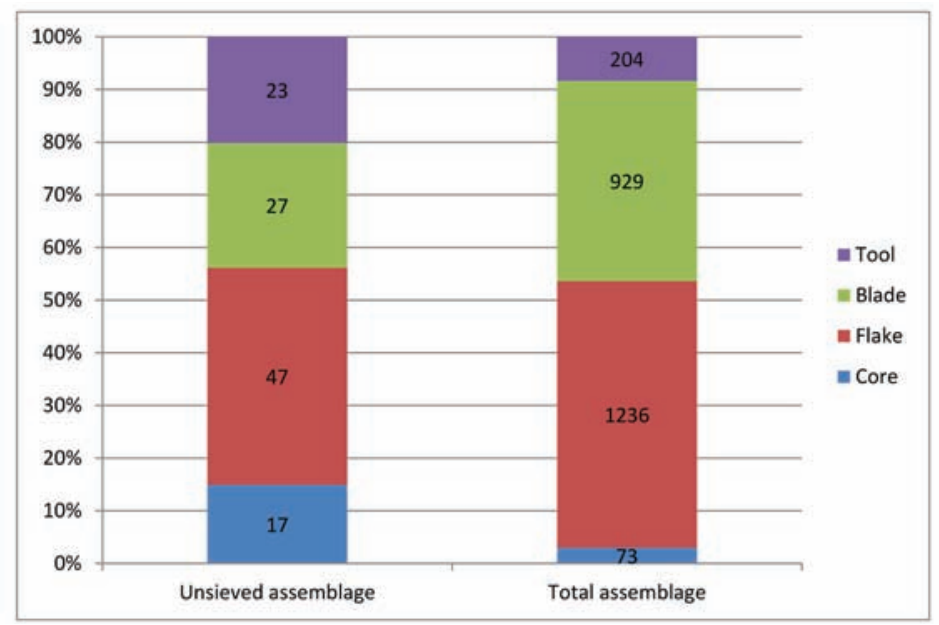

Fig. 28. Distribution of the overall technological categories from Feature 205 before and after sieving. 


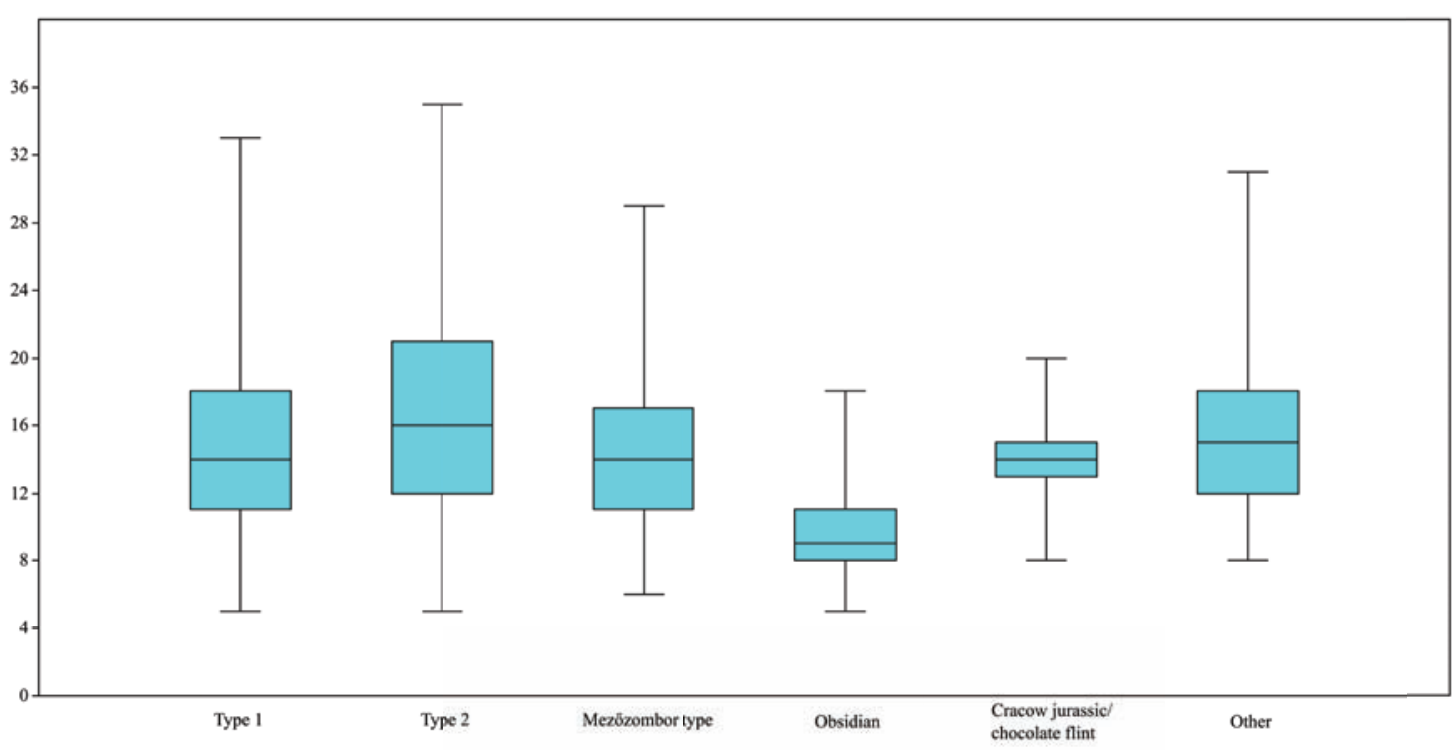

Fig. 29. Width of blades and blade fragments from Feature 205.

given enough freedom for the knapping activities and for the organization of everyday life. In some cases, only one large feature contained all the chipped products, in some cases it was distributed among two or three features, and in some cases nearly every building had such a pit. In some house groups the same houses stood for a long time, and in other house groups several buildings intersect each other, so they were less constant. In some house groups, there are little signs of a knapping activity, and in some housegroups cores were abundant in contrast to others, where the products and byproducts were numerous.

As for rites and other symbolic acts, it was impossible to distinguish them from everyday activities at a household level. However, it does not mean necessarily that there was no basic level in the Late Neolithic belief system. Although it is not fortunate to handle every settlement feature as a structured deposition, by having a closer look at the emerging suspicious

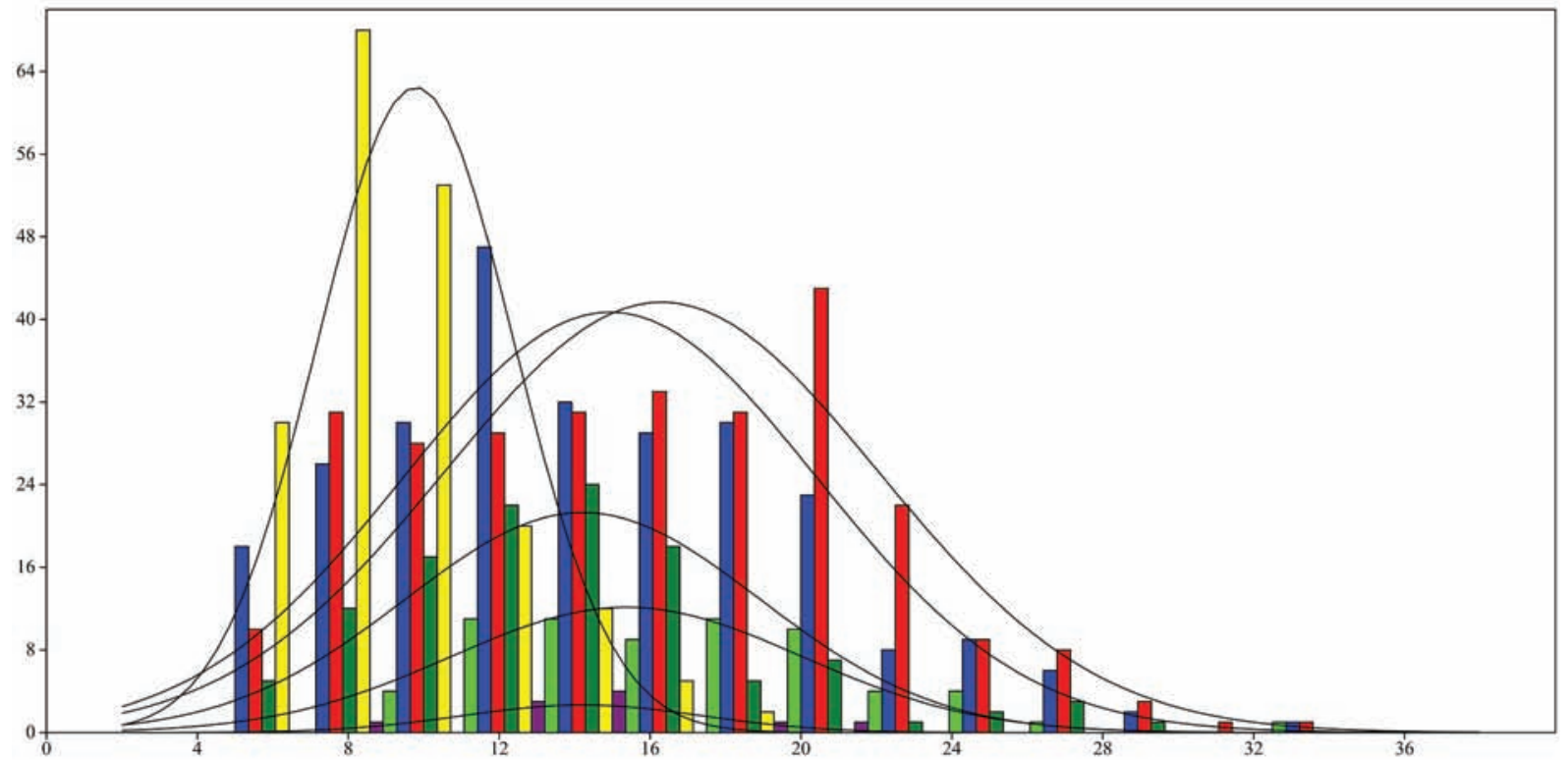

Fig. 30. Width of blades and blade fragments from Feature 205 (blue - Type 1, red - Type 2, dark green - Mezőzombor, yellow - obsidian, lilac - Cracow jurassic/chocolate flint, light green - other). 
cases, interesting observations can be conducted. The obsidian core found in an otherwise ordinary posthole is a perfect example, because it is not reflecting a regular practice at this settlement but it is rather the sign of an outdated, archaic rite. Among the 100 excavated buildings at Polgár-Csőszhalom, there is no such similar situation.

Other clues for similar acts, like the deposition in the well or the burned remains of the hearth and its infilling cannot be connected to every house groups; this kind of activity seems to be more scarce than that. In connection with Well 272, it occurred that its large vessel set could have reflected not just one household, but several ones could have taken part in the votive action. ${ }^{34}$ Either way, the amount and nature of the chipped stones in these assemblages witnessed no consistent preferences during their choice, meaning that seemingly similar pieces both played a symbolic role during the rite and were used in an everyday context. Having a closer look at them and their exact position, a strict depositional intention can be revealed as they are reflecting a virtual chaîne opératoire. Generally, tool-making process is defined not just by natural laws as needs, but it has a strong human part also, which is culturally determined similarly to other the ascpects of communal life. Therefore it is not surprising if the products of the single phases or the whole process levels up to a higher cognition state and becomes a symbol. Maybe it is not a mere accident either that the respective collection is so insignificant considering its composition that it reflects perfectly the complete knapping activity reconstructed in Polgár-Csőszhalom. Moreover, this observation is reinforced by the material of the other well excavated as Feature 966.

It is a general view that some raw materials, especially distant ones could have served as prestige objects connected to specific persons. According to the above mentioned, chipped stones might have borne significance through their technology, if they reflect special know-how, like the regular, straight intact blades detached by pressure technique. However, the graves of Polgár-Csőszhalom reflect something else. The chosen twenty cases possess very few distant raw materials, or seemingly their objects were not chosen due to their extraordinary implementation. But the majority of the deceased, who were males by the way, were middle aged, and they were accompanied by complete blades or blade fragments, trapezes, or truncated blades. The most frequent tool at the settlement, the end-scraper was scarce in the graves, and even those rare pieces were rather attributed to women. Considering the spatial position of these burials, they were distributed evenly all around the excavated surface, thus they can be classified according to the observed house groups. Usually one to three burials were accompanied by them, but several house groups lacked any burials with chipped stone grave goods.

We can find the parallels of these phenomena on the tell also, but with adaptation to the completely different governing principles of this location. With other words, the tell and the horizontal settlement differed from each other fundamentally, and they played a different role in the life of the community of Polgár-Csőszhalom. If the tell is considered a monument that represents the whole settlement and gives place for actions interpreted at higher cognitive levels, then the differences experienced among the two chipped stone assemblages must be interpreted at a global level also. According to the evaluation of the raw material composition at the two localities, it means that the Mezőzombor type and the distant raw materials had a significant role at a high social and cultural level, but this did not have any impact at the level of everyday life, and it did not have any effect on lower social units or single persons. 


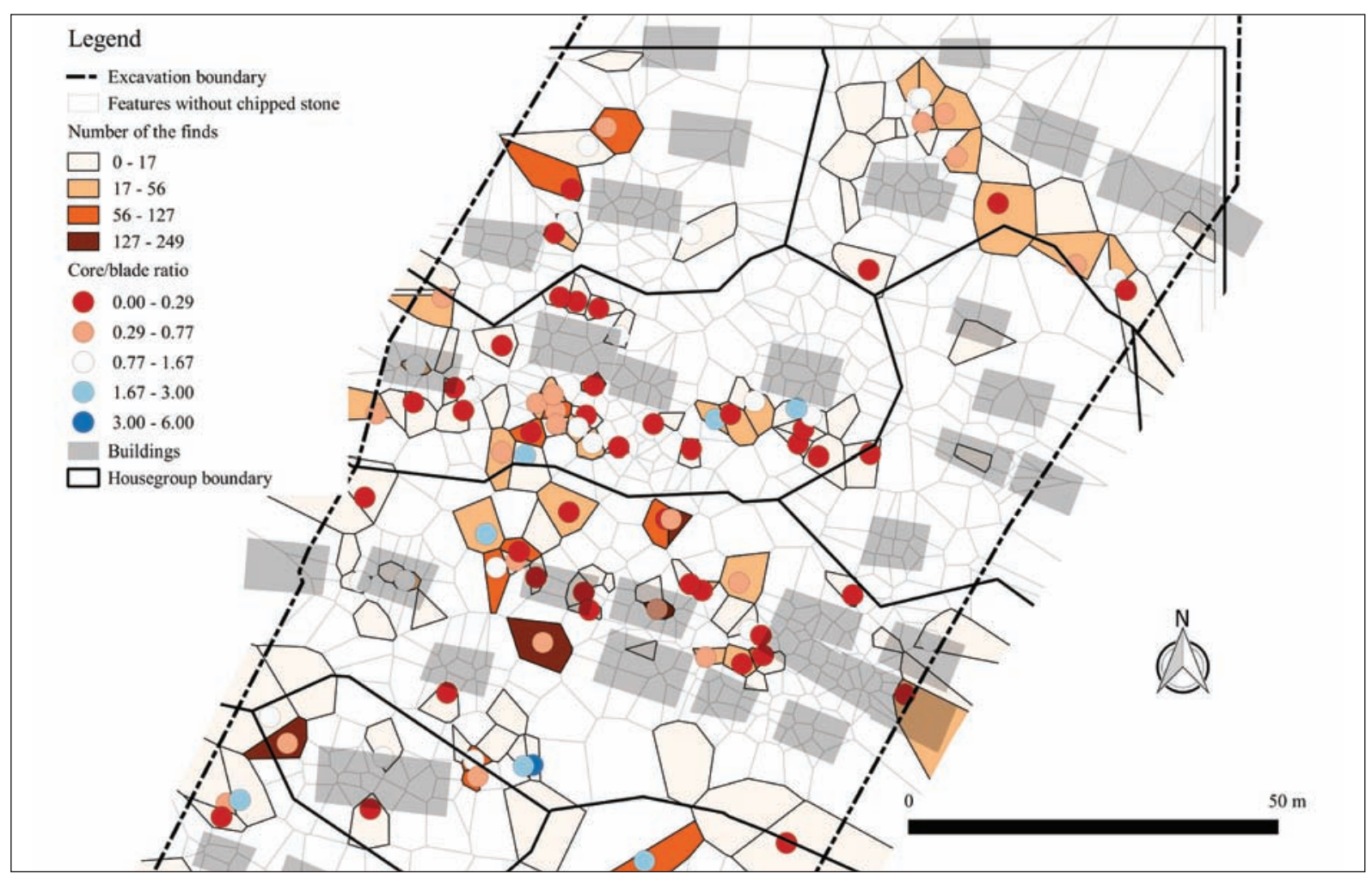

Fig. 31. The position of housegroups in the northern quarter of the excavated surface. The red tone of Thiessen polygons indicate the overall frequency of the three main limnosilicite types, while the dots represent core/blade ratio. Blue dots means higher core occurence.

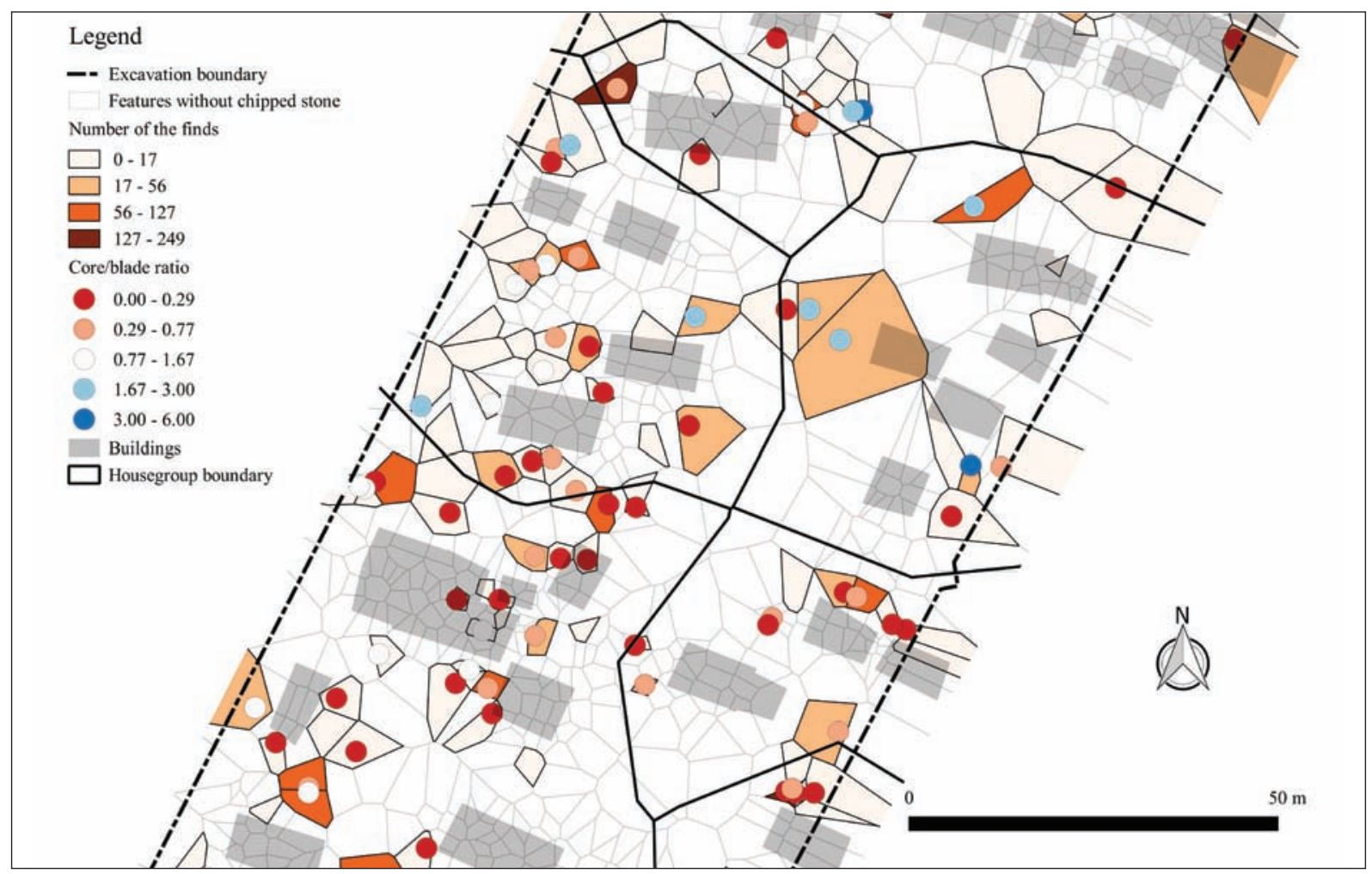

Fig. 32. The position of housegroups in the second quarter of the excavated surface. The red tone of Thiessen polygons indicate the overall frequency of the three main limnosilicite types, while the dots represent core/blade ratio. Blue dots mean higher core occurence. 


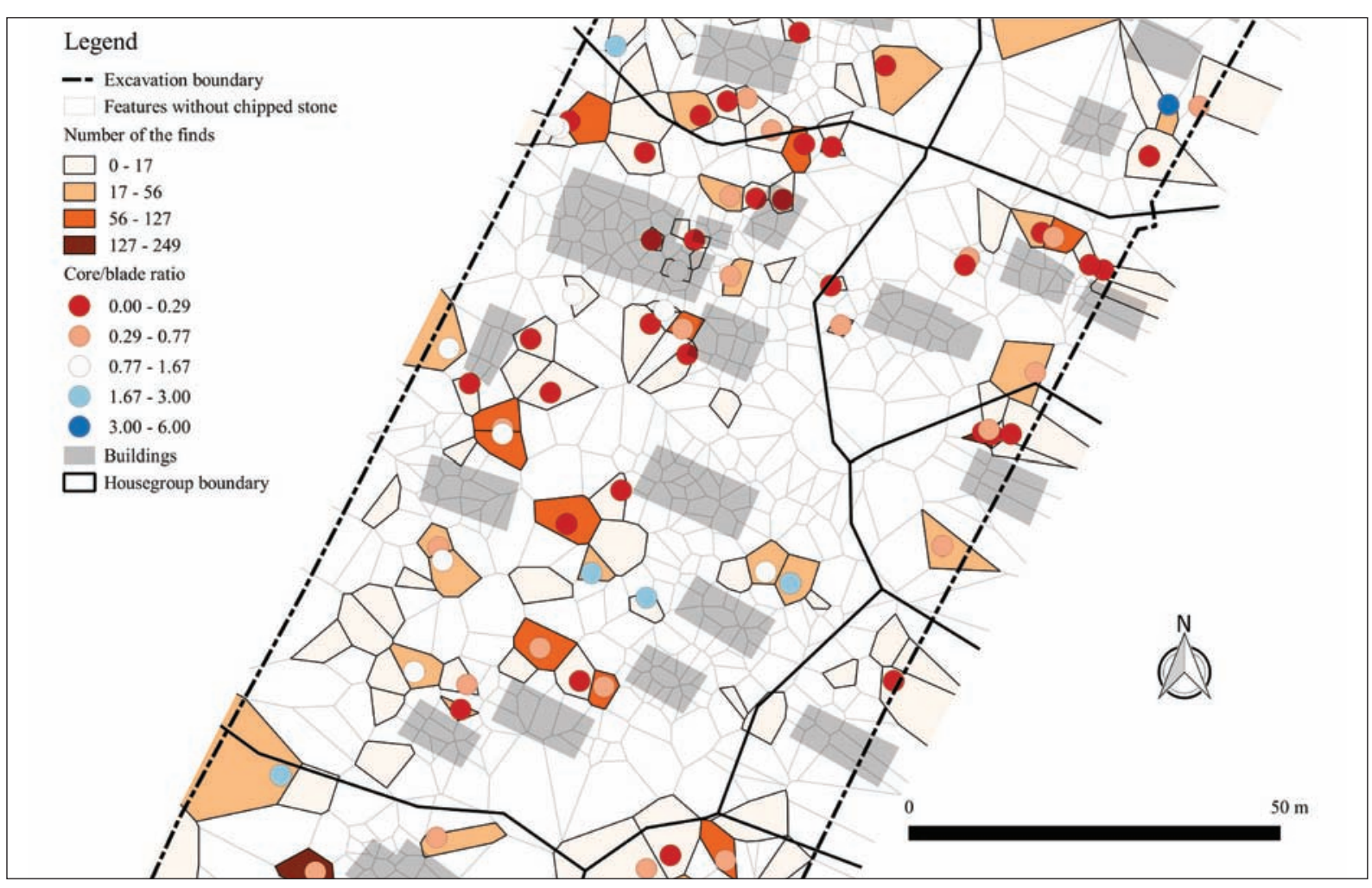

Fig. 33. The position of housegroups in the third quarter of the excavated surface. The red tone of Thiessen polygons indicates the overall frequency of the three main limnosilicite types, while the dots represent core/blade ratio. Blue dots mean higher core occurence.

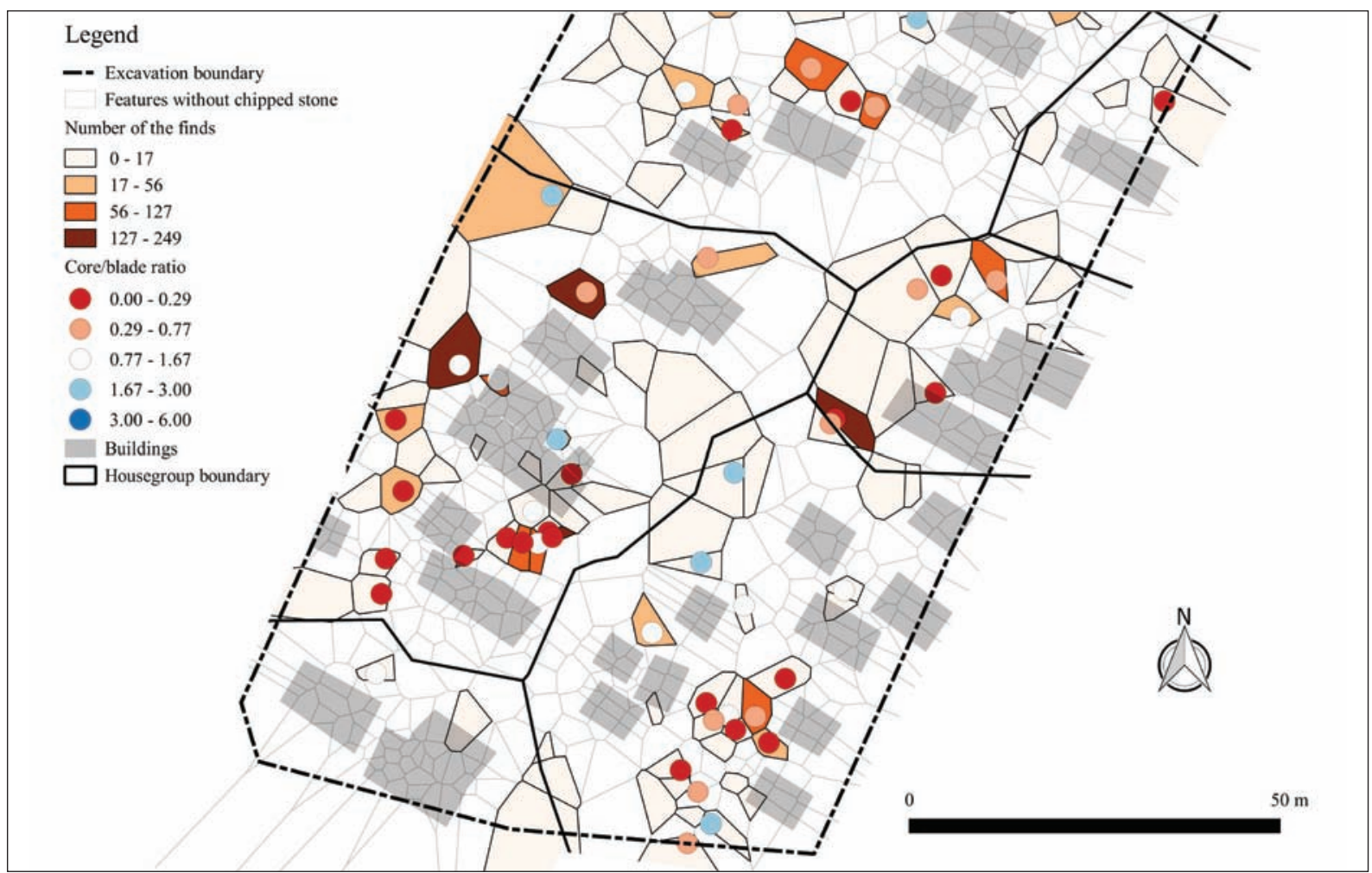

Fig. 34. The position of housegroups in the southern quarter of the excavated surface. The red tone of Thiessen polygons indicates the overall frequency of the three main limnosilicite types, while the dots represent core/blade ratio. Blue dots mean higher core occurence. 
The location where the tell stood later had been particular even in this earliest period, because the unique, two-story building had been erected exactly here. However, the chipped stone assemblage connected to this very early period was not particular in any sense. As time passed by, the cyclic filling, building, and destructing actions were applied as media for the materialization of a high-level belief system and it was observed in the chipped stone raw material preferences also. The onetime society gradually turned to distant raw materials, but it affected only the assemblage of the tell, while in the field of the domestic activity and in the domain of the lower levels of the belief system this association was not manifested at all.

The last remaining aspect is connected to the excavation technique, because the two main settlement parts were researched in different times by totally different excavation methods. Several international Paleolithic examples show that the accurate, square-meter system is indispensable to spatially reconstruct the knapping activity. However, the evaluation presented here proved that the bias caused by the excavation method here is moderated despite the theoretical loss of 96 percent of the chipped stones. The remaining 4 percent is very demonstrative concerning the tool manufacturing method and its phases. The most sensitive topic in this sense is the question of the different raw materials, because it is plausible that the obsidian could have been more frequent at the settlement while the rest of the raw materials were more balanced. However, the ratio of distant raw materials still remained very low. Among the technological categories, those were absent that represent the finer preparation actions or represent the smaller debitage products. While these pieces occurred after the sieving, it is rather plausible that the knapping activity took place in the vicinity of the pit. The composition of the retouched tool kit did not change significantly, and their ratio altogether remained at 10 percent. Among the different types, end-scrapers dominated, while other, rarer types like borers, burins, trapezes became more visible.

\begin{tabular}{|c|c|c|c|}
\hline & $\begin{array}{l}\text { Short range } \\
\text { Spatially - 5-10 m } \\
\text { Temporally - season, } \\
\text { couple of years }\end{array}$ & $\begin{array}{l}\text { Medium range } \\
\text { Spatially - 30-60 m } \\
\text { Temporally - couple of decades, } \\
\text { lifetime }\end{array}$ & $\begin{array}{l}\text { Long range } \\
\text { Spatially }-80 \mathrm{~m}< \\
\text { Temporally - couple of life- } \\
\text { times, century< }\end{array}$ \\
\hline $\begin{array}{l}\text { Flat } \\
\text { settlement }\end{array}$ & $\begin{array}{l}\text { - heterogeneous pattern } \\
\text { - periodic, short activities } \\
\text { - small assemblages } \\
\text { - domestic rites? } \\
\text { ACTIVITY ZONES }\end{array}$ & $\begin{array}{l}\text { - homogenous pattern } \\
\text { - sum of activities of longer } \\
\text { periods } \\
\text { - larger assemblages } \\
\text { - burials } \\
\text { HOUSEGROUPS }\end{array}$ & $\begin{array}{l}\text { - heterogeneous pattern } \\
\text { - spatial shift of the settlement } \\
\text { in a larger timeframe? } \\
\text { - different organizational level } \\
\text { of the society? } \\
\text { - extensive structured deposi- } \\
\text { tions (well, hearth) } \\
\text { ZONES FOR DIFFERENT } \\
\text { PURPOSES? }\end{array}$ \\
\hline Tell & $\begin{array}{l}\text { - heterogeneous pattern } \\
\text { - periodic, short activities } \\
\text { - small assemblages in a } \\
\text { layer } \\
\text { - structured depositions } \\
\text { (below and/or on the } \\
\text { floor) }\end{array}$ & $\begin{array}{l}\text { - homogenous pattern } \\
\text { - sum of activities of longer pe- } \\
\text { riods } \\
\text { - assemblage of a complete level } \\
\text { - burials } \\
\text { - leveling-building-destruct- } \\
\text { ing-filling cycle }\end{array}$ & $\begin{array}{l}\text { - heterogeneous pattern } \\
\text { - changes in a larger timeframe } \\
\text { - full sequence of the levels } \\
\text { - whole community } \\
\text { - tell as a symbol }\end{array}$ \\
\hline
\end{tabular}

Fig. 35. The theoretical model of the distribution of lithics on the two settlement units. 
To obtain further insights regarding the past social structure of Polgár-Csőszhalom, it is necessary to evaluate the chipped stones in a more detailed and focused technological and typological manner in the future, which could mean in this sense refitting and use-wear analyses. Moreover, other categories of archaeological evidence, like pottery, animal bones, etc. need to be evaluated in order to compare them with each other. The establishment of the internal chronology remains a crucial task as does the symbolic interpretation of the settlement's components, and the structural analysis of the buildings and the settlement. In future investigations, network analysis would be a more precise method to note the latent relations between the features, the archaeological evidence, and the wider region.

\section{References}

Anders, A. - Raczky, P. 2013: Háztartások és települési egység viszonya a Polgár-Csőszhalom késő neolitikus lelőhelyén (The relation between households and settlement units at the Late Neolithic settlement of Polgár-Csőszhalom). Ősrégészeti Levelek 13, 78-101.

Bailey, G. 1981: Concepts, Time Scales, and Explanation in Economic Prehistory. In: Sheridan, A. BAILey, G. (eds): Economic Archaeology. BAR International Series 96. 97-117.

BAILEY, G. N. 2007: Time perspectives, palimpsests and the archaeology of time. fournal of Anthropological Archaeology 26, 198-222.

BARtosiewicz, L. 1988: Water-sieving experiment at Örménykút, Site 54. In: JÁRó, M. - KöLtő, L. (szerk.): Archaeometrical Research in Hungary. Budapest, 267-274.

BÁcskay, E. 1976: Early Neolithic Chipped Stone Implements in Hungary. Dissertationis Archaeologicae 2/4. Budapest.

BÁCsKAY, E. 1989: A lengyeli kultúra néhány DK-dunántúli lelőhelyének pattintott kőeszközei (Chipped stone implements in some localities of Lengyel Culture in SE-Transdanubia). Communicationes Archaeologicae Hungaricae, 5-21.

BÁcsKaY, E. 1990: A lengyeli kultúra pattintott kőeszközei a DK-Dunántúlon II. (The chipped stone industry of Lengyel culture in South-East Transdanubia II). Communicationes Archaeologicae Hungaricae, 59-65.

BÁCSKAY, E. 2014: Study of microscopic use wear (microwear) on prehistoric chipped stone tools from Hungarian sites. In: T. Biró, K. - Markó, A. - Bajnok, K. P. (eds): Aeolian Scripts. New Ideas on the Lithic World: Studies in Honour of Viola T. Dobosi. Inventaria Praehistorica Hungariae 13. Budapest, 225-234.

BÁcskay, E. - T. Biró, K. 2002: Part IV: Preliminary results from the investigation of the lithic material from the flat settlement. In: Raczky, P. - Meier-Arendt, W. - Anders, A. - Hajdú, Zs. Nagy, E. - Kurucz, K. - Domboróczki, L. - Sebők, K. - Sümegi, P. - Magyari, E. - SzÁntó, Zs. Gulyás, S. - Dobó, K. - BÁcskay, E. - T. Biró, K. - Schwartz, Ch.: Polgár-Csőszhalom (19892000): summary of the Hungarian-German excavations on a Neolithic settlement in eastern Hungary. In: Aslan, R. - Blum, S. - Kastl, G. - Schweizer, F. - Thumm, D. (Hrsg.): Mauerschau: Festschrift für Manfred Korfman. Part 2. Remshalden-Grunbach, 833-860.

BÁnffy, E. - BognÁr-Kutzián, I. 2007: The Late Neolithic tell settlement at Polgár-Csőszhalom, Hungary, The 1957 excavation. BAR International Series 1730, Archaeolingua Central European Series 4, Oxford.

BeLl, C. 1992: Ritual Theory, Ritual Practice. New York.

T. Bıró, K. 1989: A lengyeli kultúra dél-dunántúli pattintott kőeszköz-leletanyagainak nyersanyagáról I. (On the Raw Material of the Chipped Stone Industry of South-Transdanubian Lengyel-Culture sites) Communicationes Archaeologicae Hungaricae, 21-29. 
T. BıRó, K. 1990: A lengyeli kultúra dél-dunántúli pattintott kőeszköz-leletanyagainak nyersanyagáról 2. (On the raw material of the chipped stone industry of South-Transdanubian Lengyel culture sites. Part 2). Communicationes Archaeologicae Hungaricae, 66-76.

T. BIRó, K. 1998: Lithic Implements and the Circulation of Raw Materials in the Great Hungarian Plain during the Late Neolithic Period. Budapest.

CAmpbell, S. 2012: Rhythms of the past: Time and memory at late Neolithic Domuztepe. In: Borrell, F. - Bouso, M. - Gómez, A. - Tornero, C. - Vicente, O. (eds): Broadening Horizons 3. Conference of Young Researchers Working in the Ancient Near East. Bellaterra, 305-323.

Casteel, R. W. 1972: Some Biases in the Recovery of Archaeological Faunal Remains. Proceedings of the Prehistoric Society 36, 382-388.

Connolly, J. - Lake, M. 2010: Geographical Information Systems in Archaeology. Cambridge Manuals in Archaeology. Cambridge.

ERDÉLYi-BÁcsKay, E. 2007: Chipped stone tools from the site Polgár-Csőszhalom dűlő (Polgár 6. flat settlement) - a preliminary report. In: Kozlowski, J. K. - Raczky, P. (eds): The Lengyel, Polgár and related cultures in the Middle/Late Neolithic in Central Europe, Kraków, 279-285.

Faragó, N. 2015: Space-time Characteristics of the Chipped Stone Industry at the Polgár-Csőszhalom Horizontal Settlement. In: Hansen, S. - Raczky, P. - Anders, A. - Reingruber, A. (eds): Neolithic and Copper Age between the Carpathians and the Aegean Sea. Chronoligies and Technologies from the 6th to the 4th Millennium BCE. International Workshop Budapest 2012. Archäologie in Eurasien 31. Bonn, 49-55.

FArAgó, N. 2016: Houses, Households, Activity Zones in the Post-LBK World. Results of the Raw Material Analysis of the Chipped Stone Tools at Polgár-Csőszhalom, Northeast Hungary. Open Archaeology 2, 346-367.

FARAGó, N.: 2017: Differences in the selection of raw materials at the site of Polgár-Csőszhalom, northeast Hungary. Bulgarian e-fournal of Archaeology 7, 85-115.

Fogelin, L. 2007: The Archaeology of Religious Ritual. Annual Review of Anthropology 36, 55-71.

GARrow, D. 2012: Odd deposits and average practice. A critical history of the concept of structured deposition. Archaeological Dialogues 19, 85-115.

Gaudzinski-Windheuser, S. - Jöris, O. - Sensburg, M. - Street, M. - Turner, E. (eds) 2011: Site-internal spatial organization of hunter-gatherer societies: case studies from the European Palaeolithic and Mesolithic; Papers submitted at the session (C58) "Come in...and find out: opening a new door into the analysis of hunter-gatherer social organisation and behaviour", held at the 15th U.I.S.P.P. conference in Lisbon, September 2006. RGZM-Tagungen Band 12. Mainz.

Hamon, C. - Allard, P. - Ilett, M. (eds) 2013: The domestic space in LBK Settlements. Internationale Archäologie, Arbeitsgemeinschaft, Symposium, Tagung, Kongress 17. Rahden/Westf.

IngoLD, T. 1993: The Temporality of the Landscape. World Archaeology 25, 152-174.

Kaczanowska, M. 1985: Rohstoffe, Technik und Typologie der neolithischen Feuersteinindustrien im Nordteil des Flussgebietes der Mitteldonau. Warszawa.

Kintigh, K. W. - Ammerman, A. J. 1982: Heuristic Approaches to Spatial Analysis in Archaeology. American Antiquity 47, 31-63.

Leroi-Gourhan, A. - Brézillon, M. 1983: Fouilles de Pincevent. Essai d'analyse ethnographique d'un habitat Magdalénien (La Section 36). Gallia Préhistoire, Supplément 7. Paris.

LucAs, G. 2005: The Archaeology of Time. London.

McNiven, I. J. 2013: Ritualized Middening Practices. Fournal of Archaeological Method and Theory 20, $552-587$.

Orton, C. R. 1982: Stochastic Process and Archaeological Mechanism in Spatial Analysis. fournal of Archaeological Science 9, 1-23.

Osborne, R. 2004: Hoards, Votives, Offerings: The Archaeology of the Dedicated Object. World Archaeology $36,1-10$. 
Payne, S. 1972: Partial Recovery and Sample Bias: The Results of Some Sieving Experiments. In: Higgs, E. S. (ed.): Papers in Economic Prehistory. London, 49-64.

Raczky, P. 1998: The Late Neolithic tell of Polgár-Csőszhalom and its relationship to the external horizontal settlement in light of recent archaeological data. In: Anreiter, P. - BArtosiewicz, L. Jerem, E. - MeID, W. (eds): Man and the animal world - Studies in Archaeozoology, Archaeology, Anthropology and Paleolinguistics in memoriam Sándor Bökönyi. Budapest, 481-489.

Raczky, P. - Meier-Arendt, W. - Kurucz, K. - Hajdú, Zs. - Szikora, Á. 1994: Polgár-Csőszhalom. A Late Neolithic settlement in the Upper Tisza region and its cultural connections (Preliminary report). Nyíregyházi fósa András Múzeum Évkönyve 36, 231-240.

Raczky, P. - Anders, A. - Bartosiewicz, L. 2011: The enclosure system of Polgár-Csőszhalom and its interpretation. In: HANSEN, S. - Müller, J. (eds): Sozialarchäologische Perspektiven: gesellschaftlicher Wandel 5000 - 1500 v. Chr. zwischen Atlantik und Kaukasus : internationale Tagung, 15.-18. Oktober 2007 in Kiel. Archäologie in Eurasien 24. Darmstadt, 57-79.

Raczky, P. - Anders, A. - Sebők, K. - Csippán, P. - Tóth, Zs. 2015: The Times of Polgár-Csőszhalom Chronologies of Human Activities in a Late Neolithic Settlement in Northeastern Hungary. In: In: Hansen, S. - Raczky P. - Anders A. - Reingruber, A. (eds): Neolithic and Copper Age between the Carpathians and the Aegean Sea. Chronoligies and Technologies from the 6th to the 4th Millennium BCE. International Workshop Budapest 2012. Archäologie in Eurasien 31. Bonn, 21-48.

RAPpaport, R. A. 1999: Ritual and Religion in the Making of Humanity. Cambridge.

Sebők, K. - Faragó, N. - Hajdú, Zs. - Anders, A. - Raczky, P. 2013: Egy különleges kút és leletei Polgár-Csőszhalom késő neolitikus településéről. Archaeologiai Értesítő 138, 29-79.

Schiffer, M. B. 1983: Toward the Identification of Formation Processes. American Antiquity 48, 675-706.

Schiffer, M. B. 1996: Formation Processes of the Archaeological Record. Salt Lake City.

Smolnik, R. (Hrsg.) 2012: Siedlungsstruktur und Kulturwandel in der Bandkeramik. Beiträge der internationalen Tagung „Neue Fragen zur Bandkeramik oder alles beim Alten?!” Leipzig, 23. bis 24. September 2010. Arbeits- und Forschungsberichte zur sächsischen Bodendenkmalpflege, Beiheft 25. Leipzig.

Szekszárdi, A. - SzAKmÁNy, Gy. - T. Biró, K. 2010: Tokaji-hegység limnokvarcit-limnoopalit nyersanyagok és pattintott kőeszközök archaeometriai vizsgálata. I.: Földtani viszonyok, petrográfia. (Archaeometric analysis on limnic-quartzite limnic opalite raw materials and chipped stone tools. Tokaj mts. NE-Hungary. I.: Geological settings, petrography). Archeometriai Mühely 7, 1-17.

Tixier, J. 2012: A method for the study of stone tools - Méthode pour l'étude des outillages lithiques. Archéologiques 4. Luxembourg.

Texier, P. J. - Meignen, L. 2011: Soixante années de technologie lithique: étapes marquantes, apports et écueils. In: Delpech, F. - Jaubert, J. (ed.), François Bordes et la préhistoire. Documents Préhistorique 29. Paris, 133-139.

Thomas, K. D. - Zapata, L. 2017: The Efficiency of Flotation Compared with Other Methods for Recovering Assemblages of Terrestrial and Aquatic Gastropods from Archaeological Deposits, with Reference to the Site of Pico Ramos (Basque Country, Spain). Environmental Archaeology 23, 1-11.

Wilk, R. R. - Rathje, W. L. 1982: Household Archaeology. American Behavioral Scientist 25/6, 617-639.

Wynn, T. - Coolidge, F. L. 2010: Beyond Symbolism and Language. An Introduction to Supplement 1, Working Memory. In: Working Memory: Beyond Language and Symbolism. Current Anthropology 51/1, 5-16.

ZoffmAn, Zs. 2012: A Polgár M3/6 jelzésủ lelőhelyen feltárt kései neolitikus temető embertani vizsgálatának eredményei (The results of the anthropoligical studies of the Polgár M3/6 marked site in Late Neolithic cemetery). A debreceni Déri Múzeum Évkönyve 83, 105-126. 
